\title{
Review \\ Addressing Gender Inequities in Forest Science and Research
}

\author{
Cate Macinnis-Ng ${ }^{1,2, *(1)}$ and Xiuhua Zhao ${ }^{1}$ (D) \\ 1 School of Biological Sciences, University of Auckland, Auckland 1010, New Zealand; \\ xiuhua.zhao@auckland.ac.nz \\ 2 Te Pūnaha Matatini, University of Auckland, Auckland 1010, New Zealand \\ * Correspondence: c.macinnis-ng@auckland.ac.nz
}

check for

updates

Citation: Macinnis-Ng, C.; Zhao, X. Addressing Gender Inequities in Forest Science and Research. Forests 2022, 13, 400. https://doi.org/ $10.3390 /$ f13030400

Academic Editor: Timothy A. Martin

Received: 24 December 2021

Accepted: 26 February 2022

Published: 1 March 2022

Publisher's Note: MDPI stays neutral with regard to jurisdictional claims in published maps and institutional affiliations.

Copyright: (c) 2022 by the authors. Licensee MDPI, Basel, Switzerland. This article is an open access article distributed under the terms and conditions of the Creative Commons Attribution (CC BY) license (https:// creativecommons.org/licenses/by/ $4.0 /)$.

\begin{abstract}
Forest research and professional workforces continue to be dominated by men, particularly at senior and management levels. In this review, we identify some of the historical and ongoing barriers to improved gender inclusion and suggest some solutions. We showcase a selection of women in forestry from different disciplines and parts of the globe to highlight a range of research being conducted by women in forests. Boosting gender equity in forest disciplines requires a variety of approaches across local, regional and global scales. It is also important to include intersectional analyses when identifying barriers for women in forestry, but enhanced equity, diversity and inclusion will improve outcomes for forest ecosystems and social values of forests, with potential additional economic benefits.
\end{abstract}

Keywords: gender equality; women in forests; career development; equity; diversity; inclusion

\section{Gender in Forest Research and the Forest Sector}

Under-representation of women is common across science and engineering disciplines [1,2], and forest research is no exception. For instance, in Sweden, only $17 \%$ of the workforce were women in 2014 (up from about 12\% in the 1990s) and about 20\% of forest engineering students were women in 2019, despite gender equity policies [3]. There are a range of reasons for gender disparity in forest research, including the masculine culture of forestry [4-6] and traditional bias and perceptions that women are not well-suited to a physically demanding field [7]. While there are growing numbers of women in forestry fields, the discipline is still heavily dominated by men at the top levels of research, management and decision-making $[5,6,8]$. The forest sector includes educational institutions, academia, research and development, natural resource and other government agencies, industry, non-government organisations and community forestry [6]. There are a range of barriers to gender equity across these different settings and organisations in rural and urban landscapes. Some barriers are universal while others are specific to a particular field of work.

The value of diversity in all fields of research and education is clearly defined: a more inclusive workforce is more creative [9] and diversity fosters innovation, leading to more effective problem solving [8]. Gender bias creates barriers for people who might otherwise make significant contributions to their chosen field [8]. In community forestry, negative impacts of marginalisation of women can be particularly damaging. For instance, rural women have been excluded from decentralised forest governance structures in Southern Tanzania and this has caused an unequal distribution of the benefits of the natural resources that forests provide [10], potentially causing other social and economic problems for women and children, especially for sustainable development under a changing climate [11,12]. The exclusion of women in natural resource management is a global issue associated with the marginalisation of Indigenous communities and their knowledge systems $[13,14]$.

Forestry, like farming and other rural physical work, is seen as a masculine discipline [15]. Loggers of the 1970s were described as hardy, robust and able to endure natural 
extremes such as snow, storms and frost. Forest work was seen as hard and dangerous, but as technologies developed, loggers of the 1980s were seen more as competent operators who were mastering machines rather than nature $[15,16]$. Forest work has evolved further in more recent decades, but these stereotypes of tough and powerful men have perpetuated $[11,15,17]$. Such narratives can be particularly influential for university students or graduates entering the sector [3,16-20], potentially reducing the numbers of women entering the workforce. Despite these ongoing perceptions, concerns around women in the forest sector are largely absent or inadequately addressed in forestry research journals [11]. When gender has been included in forestry research, studies have been restricted to genderawareness rather than being truly gender transformative work [11]. We need more studies that expose and address the underlying social dynamics that create sex-based differences in workplace participation $[8,17,18,21]$ and exclusion of women from decision-making [13].

Domination of senior roles by men is not unique to forestry (e.g., [22,23]). However, a male-dominated management structure poses a risk of an ineffective working environment in addition to being a missed opportunity for improved social, ecological and economic benefits [18]. There is potential for conflict between thought leadership being expressed in the feminine (collaborative, shared leadership, community centric forms) and decisionmaking in the masculine (top-down, decisive, economically driven, neo-liberal forms). While adhering to gender stereotypes can be unproductive, women need to be recognised as leaders in forestry, but that leadership may not be expressed in the top-down hierarchical models of the past $[8,19]$. If we as regional and global communities are to realise aspirations of regenerating forests, establishing circular economies and addressing climate change, we need to continue to challenge the models of the forestry industry and research since the two are closely intertwined.

In addition to masculine stereotypes and male domination of senior roles, a range of other issues specific to particular parts of the sector have been identified in the literature. Female tertiary students studying forestry expressed a range of concerns including sexual harassment, the gender pay gap and problems with the size of specialist clothing that is designed for men [19]. Strong traditions and hierarchical relations between students contributed to the perpetuation of the masculine culture in educational institutions, despite the evolving composition of the workforce and policies for equity in forestry [24]. Toleration of sexist jokes is an example of a process that allows discrimination to continue [24], creating spaces that exclude women [3].

General issues of gender bias in the scientific community arise from less funding being awarded to women, under-representation in publishing leadership, biases in recommendations and hiring and less recognition (e.g., fewer invitations as guest speakers at conferences and receiving fewer rewards), slowing promotion and career progression [2]. A detailed analysis of the gender and geographies of IUFRO Global Congress attendees and organising committees for the conferences in 2010, 2014 and 2019 found that male scientists in the Global North dominated the conferences, especially in gate-keeping roles, and women contributed less than 1/3 of conference roles [6]. Similarly, an analysis of the editorial boards of prominent journals in environmental biology, natural resource management and plant sciences between 1985 and 2013 showed that only 16\% of subject editors were women [23]. These examples illustrate the limitations on career opportunities for women.

Perhaps more concerning is the incidence of sexual harassment. Gender-based harassment and discrimination are problematic in many male-dominated fields and they can have ongoing impacts on career success, with women in forestry being more likely to suffer harassment, and this impacts negatively on feelings of career satisfaction [25]. Furthermore, women who experience high levels of harassment see their organisations as tolerant of harassment, so managers must take allegations of harassment seriously to protect the reputation of their organisation [24]. Harassment can be used as a controlling action to diminish women's power in the forest sector, and commonly involves objectification of women through ridicule and diminishment $[3,18,24]$. It arises as a combination of structural components that enable harassment and individual actions. A pyramid of social 
support includes inequality, disadvantages and power differences at the base, moving to prejudice and dehumanisation, then cultural standard bearers, direct facilitators and finally the perpetrators [18]. Harassment will continue until the structural processes that enable individual perpetrators to act are demolished [18].

\section{Solutions to Gender Inequity}

Women bring different perspectives, experiences and ways of thinking to research and management. In forestry research (and natural resource management more generally), sustainability and gender equality are closely linked, especially in developing parts of the world [11], so solutions are essential to ensure that forests can be used to help address growing problems, such as global change. There are a range of programmes working to support and enhance gender equality in forestry within different parts of the sector. Several studies based in education environments have identified the establishment of women's networks as an effective strategy for fostering a sense of belonging and creating a more accepting environment $[3,17,21]$. The Swedish programme Supporting Women in Forestry Today (SWIFT) has raised awareness of gender issues, helped students gain skills and strategies and develop connections to encourage retention of women in forestry [17]. Networks for women in forests that extend beyond universities are also effective in allowing women to claim space as individuals and a collective [21] and are important for empowering agency and resistance [18]. For instance, Canada's Women in Wood collective (https: / / www.womeninwood.ca/about, accessed on 23 December 2021) brings together women who work with and for forests. By sharing stories and providing mentoring, the group encourages a sense of community and belonging. Similarly, Women in Forestry (https: / / www.womeninforestry.com/about, accessed on 23 December 2021) is a network of women foresters in New Zealand who predominantly work to support female business owners through support via social media channels and conferences. On an international scale, the IUFRO (International Union of Forest Research Organisations) Gender Equality in Forestry Taskforce (https://www.iufro.org/science/task-forces/gender-equality-inforestry /, accessed on 23 December 2021) is working to demonstrate the value of a diverse workforce, provide a platform for diverse voices in forestry and increase collaboration with sciences outside forestry. Importantly, the Taskforce is using intersectional methods to take stock of IUFRO structures and leadership, so the emerging action plan is based on data and evidence. This is an excellent model for all organisations wishing to overcome the over-representation of white men in management positions.

Well-planned interventions are needed to address the complex factors that cause gender inequity. We have drawn on extensive literature to compile a list of selected interventions for different actors and bodies in the forest sector (Table 1). This is not intended as an exhaustive list, but we do highlight some of the different issues at play in different parts of the sector. We encourage male colleagues in particular to carefully consider which of the interventions they might be able to use in their own work lives, and women may find this list useful for nudging men. Some men claim gender equality interventions are unnecessary and unjust [3], but the extensive list of challenges faced by women listed above shows that there is plenty of work to be done. Improving gender diversity has positive outcomes for men too through the breakdown of stereotypical ideals of masculinity [11,18], improved social openness [11,15] and development of more supportive power structures [18]. By compiling the information in a single table, we hope to demonstrate the depth of the challenge across the sector and the huge scope for action. 
Table 1. Some suggested interventions to address gender bias in the forest sector. We have avoided making suggestions for women and marginalised people because we believe the onus should not be on under-represented groups to fix themselves [2].

\begin{tabular}{|c|c|c|}
\hline Suggestions for & Details of Interventions & References \\
\hline Male allies & $\begin{array}{l}\text { Be active allies by treating women as equals } \\
\text { Challenge sexist behaviours (such as expecting women to take notes or prepare } \\
\text { the tea) } \\
\text { Acknowledge and celebrate achievements by women } \\
\text { Be aware of relevant HR processes } \\
\text { Give women development and training opportunities } \\
\text { Create safe spaces and believe women and marginalised groups when they confide } \\
\text { in you } \\
\text { Avoid gender-specific words (such as replacing 'guys' with 'folks' and 'he' with 'they') }\end{array}$ & [26] \\
\hline Educators and academics & $\begin{array}{l}\text { Establish support networks for students } \\
\text { Provide positive role models and mentors for male and female students so early career } \\
\text { men are aware of the issues and early career women are better supported } \\
\text { Provide ethnically diverse role models and information to support a culturally } \\
\text { diverse workforce }\end{array}$ & {$[17,19,27]$} \\
\hline Conference organisers & $\begin{array}{l}\text { Increase inclusion by involving more under-represented groups as members of } \\
\text { scientific committees and session chairs } \\
\text { Consider conference location for global conferences to reduce geography and cost as } \\
\text { barriers to attendance } \\
\text { Provide caregiver grants to allow parents to attend conferences }\end{array}$ & {$[6,28]$} \\
\hline Editorial board leaders & $\begin{array}{l}\text { Improve opportunities for women and minorities by improving inclusion in } \\
\text { editorial boards } \\
\text { Encourage associate editors to seek reviewers from diverse groups and different parts } \\
\text { of the globe }\end{array}$ & [23] \\
\hline $\begin{array}{l}\text { Institutions and } \\
\text { employers/managers }\end{array}$ & $\begin{array}{l}\text { Develop diversification programmes and remove biased hiring and } \\
\text { promotions processes } \\
\text { Design recruitment and retention techniques to target specific population groups } \\
\text { Collect and publish data on diversity in the workplace } \\
\text { Reduce penalties for those who speak up } \\
\text { Introduce robust policies and processes to reduce discrimination and harassment } \\
\text { Ensure marketing material presents positive images of women playing an active role } \\
\text { in work } \\
\text { Avoid having sole woman members in a team to reduce marginalisation } \\
\text { Support flexible working environments to accommodate family responsibilities }\end{array}$ & {$[2,9,27,29]$} \\
\hline Researchers & $\begin{array}{l}\text { Develop research that uses interdisciplinary approaches to develop a deeper } \\
\text { understanding of the power dynamics and social structures that influence } \\
\text { gender inequities } \\
\text { Extend the diversity discourse to include equity, social justice and intersectionality } \\
\text { Engage with diversity scholarship in other fields } \\
\text { Use multi-level participatory approaches and methods (rather than extractive studies) } \\
\text { as best practice when working with communities }\end{array}$ & {$[11,30,31]$} \\
\hline
\end{tabular}

One of the solutions to the lack of women in forestry suggested by students is having more visible women in forestry to act as role models [19]. Showcasing women in science helps to raise profiles of individuals and make the research space more welcoming. The XXV IUFRO world congress in Curitiba, Brazil, in September-October 2019 had a number of sessions focused on gender equality and keynote speakers included an excellent balance of different genders, ethnicities, career stages and expertise [6]. Similarly, Smith et al.'s recognition of women leaders in Fire Science [32,33] was well-received on social media and more broadly as an opportunity to celebrate diverse contributions to research on fire. We acknowledge the importance of role-models as sources of inspiration and hope. We often look to senior researchers as role-models, but we argue that emerging researchers can also be excellent role-models and leaders in a changing research landscape. In our collection of 
role-models (below), we have chosen to prioritise diversity of disciplines and geographical locations of researchers over seniority, although we have included some senior researchers.

\section{Approach to Compiling Our Showcase}

We used Google Scholar to identify women researchers working in forestry across the wide scope of the journal Forests. We used self-defined 'labels' in Google Scholar to find researchers working in different sectors. Key words searched were: forest, forest ecology, forest management, forest economics, silviculture, forest entomology, forest pathology, forest ecophysiology, forest genetics, forest and global change, forest carbon, forest engineering, tropical forest, forest inventory, forest remote sensing, forest soil, forest simulation modelling, forest recreation, forest fire, wood properties, human dimensions of forests and urban forests. Where photographs were available on Google Scholar, these were used to filter researchers. When photographs were not available in Google Scholar profiles, we used Google searches to confirm the gender of researchers (if possible). We acknowledge this is a problematic approach because it is an unreliable method, and many researchers were excluded because we could not confirm their gender. For many of the key words, there were only two to three women researchers on Google Scholar. For the more popular labels such as forest ecology, we selected the top six researchers based on Google Scholar citations.

We emailed 75 women and transwomen to ask them if they would be willing to be included in a manuscript showcasing the range of current work undertaken by women. We acknowledge that this is only a very small proportion of women researchers in the field. Rather than aiming for a complete list, we sought to include a diverse range of research fields, geographical locations, ethnic backgrounds and career stages. We also used our networks to identify women not on Google Scholar who expanded the geographical representation of our group. We encourage all women researchers to set up a Google Scholar page (with a photograph and some key words to reflect research interests) to increase their visibility globally. Signing up to online databases such as Diversity EEB (https: / / diversifyeeb.com/, accessed on 23 December 2021) and Diversify Plant Sci (https:/ / rdale1.shinyapps.io/diversifyplantsci/, accessed on 23 December 2021) is another measure that women can take to increase their profile. Women who agreed to have their profiles included in this paper submitted a brief outline of their work with reference to relevant papers. Profiles were minimally edited for consistency.

\section{Showcase of Women Forest Researchers}

Cristina Aponte is a researcher at the Department of Environment and Agronomy at the Spanish Institute for Agricultural Research (INIA). Dr. Aponte's research focuses on understanding the impacts of natural and anthropogenic disturbances, such as wildfires and prescribed burnings, on forest dynamics and carbon stocks. Her notable works include quantifying the tree mortality and forest carbon changes associated with prescribed fires [34-38]. Her recent works have included an analysis on the changes in high-fireseverity patterns in southern Australia [39,40] and their long-term influence on forest canopy structure [41,42].

Jodi N. Axelson is an Assistant Cooperative Extension Specialist in Forest Health at the University of California, Berkeley (on leave), and a Research Lead in Silviculture with the British Columbia government. Jodi's research lies within the broad domain of applied ecology and forest health, focusing on forest response, recovery and resilience to management activities and/or disturbances. Dr. Axelson uses a variety of quantitative tools, such as forest biometrics, dendrochronology and wood anatomy, to study these dynamics across spatial and temporal scales. Notable works include her research on stand dynamics following mountain pine beetle outbreaks [43,44], tree growth response [45] and wood anatomical characteristics due to western spruce budworm defoliation [46]. Her recent efforts have focused on interdisciplinary collaboration, communicating the drivers of massive tree mortality events to the public, land managers and policy makers $[47,48]$, 
and on Twitter (@DisturbedDendro) and co-leading the California Tree Mortality Data Collection Network.

Susana Barreiro is an assistant professor of forest inventory and modelling at the School of Agriculture (ISA), University of Lisbon. She is presently the coordinator of IUFRO Division 4.02.07 on large-scale forest inventory and scenario modelling and a board member of the facility for planted forests (former EFIATLANTIC). Her research interests lie in the field of forest inventory, modelling and large-scale forest simulators, and extend to forest management, disturbance impacts, ecosystem services, forest economic analysis and its integration into these tools. Originally, her research focused on the development of a demand-driven regional simulator for eucalypt plantations in Portugal based on forest inventory data $[49,50]$. The need for tools to address forest managers' needs led to the development of a management-driven forest simulator capable of covering a wider range of tree species [51]. More recently, the opportunity to coordinate an international research network on wood availability in Europe led to a review on similar projection systems across Europe [52], which was further extended to cover North American tools, having been compiled in a book format [53].

Elizabeth W. Boyer is a professor of water resources at the Pennsylvania State University. Her research explores coupled hydrological, ecological and geological processes affecting water resources-at local, regional and global scales. Much of her work in forested watersheds has focused on quantifying status and trends of water quality, and cumulative watershed effects on downstream waters, in response to factors such as air pollution, climatic variability, land-use change and energy development [54-57]. Such work provides a scientific basis for policies and management strategies to mitigate the effects of environmental pollution and to protect, conserve and restore surface waters.

Deborah A. Clark is a research professor and adjunct professor of biology at the University of Missouri, St. Louis. Her research, multi-disciplinary and often team-based, has built from the continuous field studies she has jointly maintained with D.B. Clark in the tropical rainforest at La Selva, Costa Rica, over more than three decades. Initially focused on tree population ecology [58], the research turned to climate change when the data revealed depressed tree growth in warmer years [59]. The field monitoring was then expanded to the ecosystem level, addressing many aspects of the forest carbon cycle and their climatic and $\mathrm{CO}_{2}$ responses and directional trends [60,61]. A recent review focused on the existing tropical forest field data, that can serve to benchmark the global process models [62].

Morgan A. Crowley is a Ph.D. Candidate in the Department of Natural Resources at McGill University, Canada, trained in remote sensing, landscape ecology, forest fire ecology and social-ecological systems [63]. In her doctoral research, she fuses open-access satellite data to map and analyse Canadian forest fires in collaboration with the Canadian Forest Service [64,65]. Before starting her Ph.D., she researched forest management and wildfire risk in Eastern Oregon, USA [66]. Ms. Crowley facilitates Ladies of Landsat, an international organisation working to make the field of remote sensing more inclusive for under-represented scientists, and was recently named one of Geospatial World's 50 World Rising Stars 2021.

Corina Graciano is a researcher at Instituto de Fisiología Vegetal (CONICET-Universidad Nacional de La Plata) and a professor at Facultad de Ciencias Agrarias y Forestales, Argentina. Her research focuses on tree ecophysiology of exotic and native timber species. Her notable works include evaluating nutrient-water interactions $[67,68]$ and plant responses to pathogens $[69,70]$. Her recent works have included evaluating strategies to restore degraded rain forests with native trees in the Atlantic Forest in Argentina [71].

Faith Ann Heinsch is a physical scientist with the USDA Forest Service Rocky Mountain Research Station. A member of the Fire Modelling Institute, she helps bridge the gap between research and fire management, providing tools, modelling systems, workshops, training materials and user support to wildland firefighters. Dr. Heinsch maintains and provides user support for the BehavePlus fire modelling system [72], originally developed 
by Patricia A Andrews, and for the FireFamilyPlus, which models fire danger. She has contributed to research on fire behaviour in masticated fuel across the western US [72] as well as the relationship between large fire occurrence and fire danger indices [73,74].

Nikoleta Jones is currently a Principal Research Associate at the Department of Land Economy, University of Cambridge. Dr. Jones is an environmental social scientist, and her work focuses mainly on assessing social impacts of environmental policies and developing a new theoretical framework explaining public acceptance for policy initiatives in different fields, including forest management [75], protected areas [76,77] and climate change [78]. She is currently leading the project FIDELIO funded by the European Research Council, exploring how social impacts of European Protected Areas change through space and time. Dr. Jones will be joining Warwick University as an Associate Professor in July 2021.

Brooks A. Kaiser is a professor of environmental and resource economics at the University of Southern Denmark. Her research in forests and forested watersheds spans questions of resource use and governance ranging in time and space, from how Athens met its timber requirements in the Classical Era (509-322 BCE) to the evolution and value of multifaceted Hawaiian forested watershed resources and their conservation over the past century [79-81], as well as threats to these values from invasive species [82], to how requirements for environmental impact statements in the National Environmental Protection Act (NEPA, 1970) affected resource allocations and decision-making in US National Forests [83].

Leda N. Kobziar is an associate professor of wildland fire science and Director of the Master of Natural Resources program at the University of Idaho. She served as the first female president of the Association for Fire Ecology from 2016 to 2018. Dr. Kobziar's research focuses on the ecology of prescribed fire and fuel management as applied to forest soils and vegetation. Her notable works include a critique of the use of the historical fire regime concept in fire management [84], a meta-analysis to test assumptions about the response of soil microbes to heating from wildland fire [85] and contributions to a synthesis describing the fundamental ecological roles of fire [86]. Her recent work has established pyroaerobiology as a new field, exploring the consequences of wildland fire smoke transport of viable bacteria and fungi [87], and has explored the likelihood of wildland fire smoke transport of pathogenic microbes around the globe [88].

Jessica Leahy is a professor of human dimensions of natural resources in the School of Forest Resources at the University of Maine, USA. Dr. Leahy's research focuses on environmental attitudes and behaviours towards forests, forestry and other natural resource management topics using social psychology and communication approaches. Her notable works include assessing trust [89] and social capital [90] between communities and land management agencies, as well as measuring the social acceptability of forestry and forest products [91]. Her recent works include wind power conflicts [92], river restoration and collaboration [93] and the social acceptability of emerging forest products [94].

Hui Liu is an associate professor at the South China Botanical Garden, Chinese Academy of Sciences, Guangzhou, China. Dr. Liu studies the link between plant ecology, geography and phylogeny to understand how plants adapt, distribute and evolve through their functional traits. Her notable works include clarifying how woody species coordinate their hydraulic traits and height at the global scale [95], extending the hydraulic segmentation hypothesis that species in wet biomes have more vulnerable branches than leaves [96], and performing phylogenetic comparative studies on functional traits across species in Magnoliaceae [97,98], Poaceae (not listed) and other plant clades. Her work also includes the adaptations of Magnoliaceae species to drought environments of different seasons [99,100] and regions [101], based on their functional traits (mainly plant hydraulic traits).

Juxiu Liu is a professor at the South China Botanical Garden, Chinese Academy of Sciences, Guangzhou, China. Dr. Liu focus on the impacts of environmental change, especially carbon and nitrogen deposition on subtropical forest ecosystems in South Asia [102-105]. 
Her recent work includes the analysis of bioregulation mechanisms and influencing factors of the phosphorus cycle in subtropical forests in South China [106,107].

Dr. Wan-Yu Liu is a professor at National Chung Hsing University (NCHU), Taiwan. Her research interests include forest policy and economics [108], forest/farm tourism [109], environmental economics [110] and modelling and evaluation of GHG reduction policies. Her work also focuses on climate change and forest carbon sequestration analysis [111], as well as forest management [112].

Carol A. Loopstra is an Associate Professor in the Department of Ecology and Conservation Biology at Texas A\&M University. Dr. Loopstra's research focuses on adaptation and genomics tool development in loblolly pine, especially in the western part of the natural range in the south-eastern USA. A major contribution to the genomics community was the discovery of $\sim 2.9$ million single nucleotide polymorphisms at a time that most association studies involved less than 5000 [113]. These SNPs were later used for association analyses with growth and adaptive traits, gene expression and metabolite levels and geographic and climate variables [114-116]. Current research is linking genomics tools to tree improvement, especially adaptation to water-deficit stress. Dr. Loopstra is the editor for the Forests section "Genetics and Molecular Biology".

Rima D. Lucardi is a Research Ecologist with the Southern Research Station of the United States Forest Service. Dr. Lucardi's research program focuses on invasive species and threats to natural and managed forestlands. Her utilisation of several approaches seeks to elucidate genetic variability and plant invasion success [117] in evaluating possible remediation of the impact and spread by invasive species among federal, state and private forests. Dr. Lucardi has researched insect and pathogenic threats to a keystone tree species of the North American Appalachian Mountain range [118] and rare plants of the forest understory [119]. Her current research is to build strong collaborations among many sectors of society [120] to create innovative research that generates empirical data from which to test hypotheses within biological invasion theory, and more practically, prevent high-risk global plant invasions [121].

Joan Luther is a research scientist at the Atlantic Forestry Centre of the Canadian Forest Service and an adjunct professor at Memorial University and the University of Sherbrooke, Canada. Her research focuses on developing remote sensing and geospatial methods to characterise boreal forest ecosystems in support of sustainable resource management. Her notable works include contributions to mapping the land cover of Canada [122], modelling forest attributes [123-125] and monitoring forest change [126]. Her recent work includes techniques for enhancing forest inventories using optical and LiDAR (Light Detection and Ranging) technologies [127].

Cate Macinnis-Ng is an Associate Professor and Rutherford Discovery Fellow in the School of Biological Sciences at the University of Auckland. Dr Macinnis-Ng is interested in the ecophysiology of trees under global change. Her current focus is on carbon and water fluxes of native forests of New Zealand [128-131]. She also contributes to global analyses of forest dieback [132,133] and ecosystem function [134].

Brenda McComb (formerly known as William McComb) is an Emeritus Professor and Dean at Oregon State University. Brenda's research has focused on the relationships between forest structure and habitat for a wide variety of species at local, landscape and regional scales. Her work spans habitat relationships research conducted in the Pacific Northwest, Northeast and Deep South of the USA, as well as in Western Australia. At the stand scale, she co-authored papers with Dr. Carol Chambers, documenting the response of birds to various silvicultural treatments [135]. At the landscape scale, she has publications with former graduate students Drs. Kevin McGarigal and Karl Martin, that documented vertebrate habitat relationships to forest pattern and composition at watershed scales [136-138], as well as several papers with Dr. Tom Spies and others that estimated responses of several focal species to various forest policies at the regional scale [139-141]. Her recent work has included several textbooks that are used in courses that she continues to teach $[142,143]$. 
Angela Lo Monaco is an associate professor of wood technology and forest logging. Her research interests mainly concern wood science and technology for both the environment and cultural heritage. In her work, she has given priority to the creation of research networks. Her primary research interests focus on the properties of wood in historically and artistically significant artefacts [144], paying particular attention to the characteristics of wood degraded by environmental factors, where the colour and chemical characteristics of surfaces are used as monitoring systems [145]. The impacts of logging on residual trees [146] and seedlings [147] as well as the influence of human activities on the quantity and quality of dead wood in the forest $[148,149]$ are further topics of her research activities. Her recent research work concerns wood modification [150] and the negative effect of skidding operations on runoff and sediment yield [151].

Adriane Esquivel Muelbert is a lecturer in Global Forest Ecology at the University of Birmingham and a researcher at the Birmingham Institute of Forest Research. She investigates how forests respond to different global change forces and what the implications of these responses are on biodiversity and global biogeochemical cycles. Her work demonstrates the importance of drought tolerance in shaping diversity and composition across Neotropical tree communities [152,153] and provides evidence that Amazonian forests are changing as a result of the increase in water stress and atmospheric $\mathrm{CO}_{2}$ [154]. More recently, she has focused on tree mortality and how tree death varies across large geographical scales [155] and tree size [156]. Adriane is Brazilian-Panamanian and aims to promote science from the global south.

Guangyan Ni is an Associate Researcher and works for the South China Botanical Garden, Chinese Academy of Sciences. Dr. Ni's research focuses on understanding how exotic plants successfully invade new ranges and the impacts on the invaded forest ecosystems. Her notable works include the biogeographic comparisons of exotic plants between native and invaded ranges, the physiology of hybrid invasive plants and their relative native species and assessment of their fate under global change [157-159]. Her recent work includes how the soil microbial community is involved in carbon sequestration in invaded ecosystems [160].

Shuli Niu is a professor at the Institute of Geographical Sciences and Natural Resources Research, Chinese Academy of Sciences, Beijing, China. Her research focuses on regional and global ecology and aims to integrate and analyse the network observation and networking experimental data of terrestrial ecosystems by using data mining to reveal the large-scale patterns of key surface processes in terrestrial ecosystems and their environmental regulatory factors and mechanisms [161-163]. Her research also includes the response and adaptation of ecosystem structures and functions to global change by using global field control experiments to study ecosystem structures and functions, especially the response and adaptation of ecosystem carbon, nitrogen, water cycles and their couplings to climate change and human interference [164,165].

Rachael H. Nolan is a Lecturer at the Hawkesbury Institute for the Environment at Western Sydney University, Australia. Dr. Nolan's research focuses on quantifying the impacts of disturbances, such as fire and drought, on tree mortality, water resources and forest carbon stocks. Her research also focuses on quantifying the drivers of forest flammability (e.g., fuel dryness and fuel loads). Notable works include her research on physiological responses of forests to drought stress [166] and fire [167], as well as her work on the physiological underpinnings of variation in live fuel moisture content $[168,169]$. Her recent work has included analyses on the causes and consequences of the 2019/2020 bushfires in eastern Australia [170], which drew on historical analyses of bushfires in the region [171].

Elena Paoletti is a forest ecophysiologist at the Institute of Research on Terrestrial Ecosystems (IRET) of the Italian National Council of Research (CNR). Elena's research focuses on understanding mechanisms of action and effects of climate change factors on the forest environment $[172,173]$, in developing new methods for exposing whole trees to ozone pollution [174] and for monitoring ozone and climate change impacts on forests [175], and in 
improving global awareness of the risks of climate change for forests [176]. She discovered a new mechanism of stomatal response to ozone, called stomatal sluggishness [177]. Elena is active in the International Union of Forest Research Organizations (IUFRO), European Forest Institute (EFI), Chinese Academy of Science (CAS) and Italian Society of Silviculture (SISEF). She is a prolific writer and science communicator, with over 250 peer-reviewed papers in national and international journals, and an h-index of 41.

Therese Poland is a Research Entomologist and Project Leader with the USDA Forest Service in East Lansing, MI, USA. She received her Master of Pest Management and Ph.D. degrees from Simon Fraser University in Burnaby British Columbia, where she studied pheromone-based management of pine and spruce bark beetles. Her research [178-183] is on biology, management and regulatory issues related to invasive forest insect pests. She has worked on several wood-boring species, including the pine shoot beetle, Asian long-horned beetle and emerald ash borer.

Nadine Ruehr is a scientist at the Karlsruhe Institute of Technology, Germany. She is an Emmy Noether fellow of the German Research Foundation and a founding member of the International Tree Mortality Network. Her research focuses on tree and forest responses to extreme climate events, integrating experiments, observations and models. Her notable research includes biogeochemical cycling in temperate and semi-arid forests [184,185], impacts of drought and heat stress on tree carbon metabolisms and hydraulics [186]. Her recent works address trends and mechanisms of tree mortality $[187,188]$ and post-stress recovery strategies as key processes of forest resilience [189].

Mariana Rufino is a professor of agricultural systems at Lancaster University in the UK. Her research focuses on the interphase between agriculture and forests. Dr. Rufino aims to improve the understanding of and provide solutions to the competing demands on managed landscapes. Her most recent research quantifies forest ecosystem services, including water provisioning [190,191], carbon sequestration [192], contributing to climate change mitigation [193,194] and supporting adaptation [195]. Acknowledging human agency and the importance of community participation, her research team has reviewed [196], tested and implemented a citizen-science approach to monitor water in tropical montane forests [197].

Temuulen Sankey is an Associate Professor at Northern Arizona University, USA, where she leads the Remote Sensing and Geoinformatics Laboratory. Her research focuses on forest ecosystem remote sensing across the western USA and Mongolia, with LiDAR, hyperspectral and multispectral images [198-200]. Dr. Sankey develops novel UAV remote sensing to evaluate restoration impacts on forest structure [201], canopy fuels [202], forest ecohydrology, snowpack and resiliency to drought and climate change [203]. She is leading methodological developments in UAV remote sensing of genetic trait-based phenotype and genotype differences for trees in response to drought and climate stress [204].

Akiko Satake is a professor at Kyushu University, Japan. She studies phenology and reproductive synchrony in plant populations using interdisciplinary approaches that combine gene expression analyses, mathematical modelling and fieldwork [205,206]. Her recent research focus is on comparative phenology between seasonal and aseasonal forests based on field transcriptome and modelling approaches [207,208].

Ashley Schulz is a postdoctoral fellow at Colorado State University. Dr. Schulz's research focuses on the ecology, risk assessment and management of invasive pests and pathogens in forest ecosystems. Her notable work includes evaluating the tripartite interactions among eastern white pine, a scale insect and a pathogen to better understand potential drivers of eastern white pine dieback in the eastern United States [209]. Her recent work includes linking the fields of biological control and invasion ecology to elucidate mechanisms of species invasion $[210,211]$, and assisting with the development of models that will predict the probability of impact of introduced insects on North American tree species [212].

Rosemary L. Sherriff is a professor at Humboldt State University. Dr. Sherriff's research focuses on forest disturbance ecology, climate variability and forest dynamics in 
temperate and boreal forests in North America. Her notable works include comparisons of historical fire regimes with recent and potential fires to evaluate the consequences of fire regime changes for management under expected future climate in montane forests $[213,214]$, and evaluation of beetle outbreaks, climate and boreal forest change, where recent warming has affected high-latitude regions to a greater extent than other parts of the globe $[215,216]$. Recent works extend into redwood, oak and mixed conifer forests in Northern California $[217,218]$.

Laura K. Snook is an Honorary Research Fellow at Bioversity International in Rome, Italy. For 13 years, she led their international research program on the conservation of the genetic diversity of forest and woodland trees in countries in Latin America, Africa and Asia. Dr. Snook is best known for her research on the ecology and silviculture of mahogany (Swietenia macrophylla), including insights into how hurricanes followed by fires favour mahogany regeneration, which contributed to the listing of this species in CITES Appendix II [219,220]. Her work in tropical countries [221], including studies on seed production [222] and growth rates [223] of mahogany, has provided knowledge that is fundamental to sustainable forest management, while her research on community forestry has shown how it can lift rural people out of poverty while also sustaining forests and their biodiversity [224]. Other notable contributions include leading a global research program on Sustainable Forest Management at CIFOR (the Center for International Forestry Research), founding Mexico's first Master's degree program in applied ecology and her role as Vice President of the Tropical Forest Foundation.

Sandra J. Velarde is a Senior Analyst at the Climate Change Commission and was formally an Associate Research Leader in environmental economics and governance at Scion and an Associate Investigator at Te Pūnaha Matatini Centre of Research Excellence, New Zealand. Dr. Velarde's interests focus on the practice of transdisciplinary science, distilling lessons for policy design on afforestation and indigenous participation [225,226], adaptive governance systems for enhanced decision-making [227], urban green spaces, ecosystem services and biofuels. Using visual sense-making and story-telling, Sandra translates complex approaches into impactful tools, e.g., adaptive governance toolkit to support societal transformations, including a role-play serious game [228] and a toolkit to explore scenario planning with local forest communities [229].

Rachele Venanzi has a Ph.D. in Land, Environment, Resources and Health (LERH), and her research area is in agriculture and forest mechanisation and operations management. She is an assistant researcher in wood technology and forest logging works at the Department of Agriculture and Forest Sciences (DAFNE), Tuscia University, Italy. Her primary research interests focus on indices and indicators typical of sustainable forest management applied to forest operations in particular, and she is developing studies on the impact of silvicultural treatment and forest operations on soil conditions [230-234]. The aim of her research is to contribute to updating the guidelines, criteria and indicators for sustainable forest management, and Reduced Impact Logging (RIL) from a perspective of SFOs application.

Joanne White is a research scientist with the Canadian Forest Service, Natural Resources Canada, and serves on the editorial boards of Remote Sensing of Environment and Current Forestry Reports. Dr. White's research focuses on the application of remote sensing technology to improve and enhance forest monitoring and inventory [235]. She specializes in the study of 3D remote sensing for characterizing forest structure, including data from both airborne laser scanning and digital aerial photogrammetry [236-238], and has synthesised best practices in the application of airborne laser scanning for forest inventory [239]. Dr. White's recent works have focused on the application of Landsat time series data and airborne laser scanning to study long-term forest disturbance and recovery trends over large areas [240], through the use of best-available pixel compositing approaches [241].

Xiuhua Zhao is a postdoctoral research fellow of the School of Biological Science at the University of Auckland and completed her Ph.D. degree at the South China Botanical Garden, Chinese Academy of Sciences, Guangzhou, China. Dr. Zhao's research interests 
are in plant ecophysiology, specializing in plant water relations and how they respond to climate change [242-244]. Her recent works include forest water use and carbon uptake in ecosystems and climatic zones of New Zealand and China by using stable isotope methods [245] combined with an SPA model.

Liwei Zhu is an Associate Research Fellow at the South China Botanical Garden, Chinese Academy of Sciences. Dr. Zhu's research mainly focuses on sap flux characteristics of tree species and their responses to environmental variables in China. Her works include research into the effect of sap flux on the estimation of stem $\mathrm{CO}_{2}$ fluxes [246,247], the coordinated effect of stomatal conductance and hydraulic conductance on water use of eucalypt [248] and the sap flux responses of different tree species to drought [249]. Her recent work explores the relationship between wood density, functional traits of xylem and leaves and variations with temperature.

\section{Future Directions and Conclusions}

When writing this paper, we brought first-hand knowledge as two women researchers at different career stages who have grown up in quite different cultures, but we easily found common ground around the gender bias we have experienced and the different ways it has perpetuated. The power of having supportive relationships with colleagues and collaborators cannot be overstated! Dismissal of lived experiences by colleagues (particularly those in leadership roles) is disempowering and demoralising. Worse, having to argue the case can be very distressing and retraumatising. By articulating some of the challenges and providing some positive directions, we hope this paper will be used as supporting evidence and a conversation starter.

Understanding obstacles for women in their careers is essential if they are to fully participate in science and natural resource management [8]. The current research environment does not encourage research that probes the causes and consequences of gender norms in forestry, and few papers apply feminist research methods and theory in forestry so there is a lack of deeper, more nuanced analysis of how power dynamics and social structures influence gender inequities in the forest sector $[3,11]$. The global pandemic has served to increase barriers and inequities, so active approaches to combatting inequities, including compassionate mentoring, are more important than ever [250]. We listed a range of practical interventions to address barriers to women entering and remaining in the forest sector, including the sometimes-unwelcoming environment, lack of sense of belonging and lack of career opportunities [19]. We also encourage more work supporting the empowerment of women in community forestry [10]. Despite the negative aspects of reading the literature about gender bias in forest education, research and management, we did find hope in the positive stories of outstanding research and real-world impact that women in forests are having.

Our showcase is not intended to be a comprehensive list of women working in forest research, rather it is a selection of women identified through Google Scholar searching and our networks. We acknowledge that gender is just one type of diversity that is imbalanced in forest science and research. Ethnic and racial diversity are also often under-represented in research and higher degrees [251]. Intersectional research is also essential, as other factors including (but not limited to) ethnicity, sexuality and disabilities exacerbate impacts on women's careers [30]. We have attempted to include some ethnic and racial diversity in our selection of women forest scientists and researchers, but future pieces could be more specific about this. Engaging with global (IUFRO) and local networks that foster diversity in forests is currently challenging in the global pandemic, but online fora are improving global connectivity by facilitating the growth of networks without the costs of travel. A diverse workforce is better for all, so we encourage male colleagues to support and enhance gender and other diversity in forest industry and research by building an awareness of male privilege [252] and making space for diverse perspectives in all work-place activities. Amplifying marginalised voices and taking on some of the burden of addressing gender imbalances can make a huge difference. 
We are grateful to the women researchers profiled in this paper for their willingness to be included. This initiative was enthusiastically received as a positive contribution to the literature. Wider inclusion across different disciplines (particularly the social sciences) and geographical areas would be a welcome next step.

Author Contributions: C.M.-N. wrote the introduction and conclusions and co-ordinated the work. X.Z. collated and edited the contributed paragraphs for clarity and consistency. All authors have read and agreed to the published version of the manuscript.

Funding: C.M.-N. is funded by a Rutherford Discovery Fellowship from the Royal Society Te Apārangi (RDF-UOA1504) and Te Pūnaha Matatini, and X.Z. was funded by a Faculty Research Development Grant (3717388) from the University of Auckland.

Acknowledgments: We thank all the women who contributed a paragraph to this paper. We also thank Rebecca Goodyear for help compiling the paragraphs and references and Nari Williams and Tim Martin for conversations that helped shape the direction of this paper. We acknowledge allies everywhere who work tirelessly for a more fair and inclusive society.

Conflicts of Interest: The authors declare no conflict of interest.

\section{References}

1. Hill, C.; Corbett, C.; St Rose, A. Why So Few? Women in Science, Technology, Engineering, and Mathematics; American Association of University Women: Washington, DC, USA, 2010.

2. Grogan, K.E. How the entire scientific community can confront gender bias in the workplace. Nat. Ecol. Evol. 2019, 3, 3-6. [CrossRef] [PubMed]

3. Johansson, K.; Andersson, E.; Johansson, M.; Lidestav, G. Conditioned openings and restraints: The meaning-making of women professionals breaking into the male-dominated sector of forestry. Gend. Work Organ. 2020, 27, 927-943. [CrossRef]

4. Brandth, B.; Haugen, M.S. Breaking into a masculine discourse. Women and farm forestry. Sociol. Rural. 1998, $38,427-442$. [CrossRef]

5. Larasatie, P.; Baublyte, G.; Conroy, K.; Hansen, E.; Toppinen, A. "From nude calendars to tractor calendars": The perspectives of female executives on gender aspects in the North American and Nordic forest industries. Can. J. For. Res. 2019, 48, 915-924. [CrossRef]

6. Koch, S.; Matviichuk, E. Patterns of inequality in global forest science conferences: An analysis of actors involved in IUFRO World Congresses with a focus on gender and geography. For. Policy Econ. 2021, 129, 102510. [CrossRef]

7. Burley, J. Women in forestry and forest research. Int. For. Rev. 2001, 20, 64-68.

8. Kern, C.C.; Kenefic, L.S.; Stout, S.L. Bridging the gender gap: The demographics of scientists in the USDA Forest Service and academia. BioScience 2015, 65, 1165-1172. [CrossRef]

9. Anderson, W.S. The changing face of the wildlife profession: Tools for creating women leaders. Hum.-Wildl. Interact. 2020, 14, 15.

10. Killian, B.; Hyle, M. Women's marginalization in participatory forest management: Impacts of responsibilization in Tanzania. For. Policy Econ. 2020, 118, 102252. [CrossRef]

11. Asher, K.; Varley, G. Gender in the jungle: A critical assessment of women and gender in current (2014-2016) forestry research. Int. For. Rev. 2018, 20, 149-159. [CrossRef]

12. Robson, J.P.; Wilson, S.J.; Sanchez, C.M.; Bhatt, A. Youth and the future of community forestry. Land 2020, 9, 406. [CrossRef]

13. Nhem, S.; Lee, Y.J. Women's participation and the gender perspective in sustainable forestry in Cambodia: Local perceptions and the context of forestry research. For. Sci. Technol. 2019, 15, 93-110. [CrossRef]

14. Goldman, M.J.; Jagadeesh, S.N.; Ngimojino, T.M.O.; Gowda, L.M. Women's stories and knowledge of wildlife and conservation practice in northern Tanzania and South India. Oryx 2021, 55, 818-826. [CrossRef]

15. Brandth, B.; Haugen, M.S. Doing rural masculinity-from logging to outfield tourism. J. Gend. Stud. 2005, 14, 13-22. [CrossRef]

16. Kanowski, P.J. Multilateral forestry research and tertiary forestry education for development: Reflections on progress since the 1970s. Int. For. Rev. 2020, 22, 113-128. [CrossRef]

17. Crandall, M.S.; Costanza, K.K.; Zukswert, J.M.; Kenefic, L.S.; Leahy, J.E. An Adaptive and Evidence-Based Approach to Building and Retaining Gender Diversity within a University Forestry Education Program: A Case Study of SWIFT. J. For. 2020, 118, 193-204. [CrossRef]

18. Johansson, M.; Johansson, K.; Andersson, E. Metoo in the Swedish forest sector: Testimonies from harassed women on sexualised forms of male control. Scand. J. For. Res. 2018, 33, 419-425. [CrossRef]

19. Larasatie, P.; Barnett, T.; Hansen, E. The "catch-22" of representation of women in the forest sector: The perspective of student leaders in top global forestry universities. Forests 2020, 11, 419. [CrossRef]

20. Bal, T.L.; Rouleau, M.D.; Sharik, T.L.; Wellstead, A.M. Enrollment decision-making by students in forestry and related natural resource degree programmes globally. Int. For. Rev. 2020, 22, 287-305. [CrossRef] 
21. Laszlo Ambjörnsson, E. Performing female masculinities and negotiating femininities: Challenging gender hegemonies in Swedish forestry through women's networks. Gend. Place Cult. 2021, 28, 1584-1605. [CrossRef]

22. Walker, L.; Sin, I.; Macinnis-Ng, C.; Hannah, K.; McAllister, T. Where to from Here? Women Remain Absent from Senior Academic Positions at Aotearoa New Zealand's Universities. Educ. Sci. 2020, 10, 152. [CrossRef]

23. Cho, A.H.; Johnson, S.A.; Schuman, C.E.; Adler, J.M.; Gonzalez, O.; Graves, S.J.; Huebner, J.R.; Marchant, D.B.; Rifai, S.W.; Skinner, I.; et al. Women are underrepresented on the editorial boards of journals in environmental biology and natural resource management. PeerJ 2014, 2, e542. [CrossRef] [PubMed]

24. Grubbström, A.; Powell, S. Persistent norms and the MeToo effect in Swedish forestry education. Scand. J. For. Res. 2020, 35, 308-318. [CrossRef]

25. Kern, C.C.; Kenefic, L.S.; Dockry, M.J.; Cobo-Lewis, A. Discrimination and career satisfaction: Perceptions from US Forest Service scientists. J. For. 2020, 118, 44-58. [CrossRef]

26. Madsen, S.R.; Townsend, A.; Scribner, R.T. Strategies that male allies use to advance women in the workplace. J. Men's Stud. 2020, 28, 239-259. [CrossRef]

27. Balcarczyk, K.L.; Smaldone, D.; Selin, S.W.; Pierskalla, C.D.; Maumbe, K. Barriers and supports to entering a natural resource career: Perspectives of culturally diverse recent hires. J. For. 2015, 113, 231-239. [CrossRef]

28. Lerman, S.B.; Pejchar, L.; Benedict, L.; Covino, K.M.; Dickinson, J.L.; Fantle-Lepczyk, J.E.; Rodewald, A.D.; Vleck, C. Juggling parenthood and ornithology: A full lifecycle approach to supporting mothers through the American Ornithological Society. Condor 2021, 123, duab001. [CrossRef]

29. Bal, T.L.; Sharik, T.L. Web content analysis of university forestry and related natural resources landing webpages in the United States in relation to student and faculty diversity. J. For. 2019, 117, 379-397. [CrossRef]

30. Batavia, C.; Penaluna, B.E.; Lemberger, T.R.; Nelson, M.P. Considering the case for diversity in natural resources. BioScience 2020, 70, 708-718. [CrossRef]

31. Colfer, C.P.; Minarchek, R.D. Women, Men and Forest Research: A Review of Approaches, Resources and Methods for Addressing Gender; Occasional Paper 80; CIFOR: Bogor, Indonesia, 2012.

32. Smith, A.; Kolden, C.A.; Prichard, S.J.; Gray, R.W.; Hessburg, P.F.; Balch, J.K. Recognizing women leaders in fire science. Fire 2018, 1, 30. [CrossRef]

33. Smith, A.; Strand, E.K. Recognizing Women Leaders in Fire Science: Revisited. Fire 2018, 1, 45. [CrossRef]

34. Bennett, L.T.; Bruce, M.J.; Machunter, J.; Kohout, M.; Krishnaraj, S.J.; Aponte, C. Assessing fire impacts on the carbon stability of fire-tolerant forests. Ecol. Appl. 2017, 27, 2497-2513. [CrossRef] [PubMed]

35. Bennett, L.T.; Bruce, M.J.; MacHunter, J.; Kohout, M.; Tanase, M.A.; Aponte, C. Mortality and recruitment of fire-tolerant eucalypts as influenced by wildfire severity and recent prescribed fire. For. Ecol. Manag. 2016, 380, 107-117. [CrossRef]

36. Bennett, L.T.; Aponte, C.; Baker, T.G.; Tolhurst, K.G. Evaluating long-term effects of prescribed fire regimes on carbon stocks in a temperate eucalypt forest. For. Ecol. Manag. 2014, 328, 219-228. [CrossRef]

37. Aponte, C.; Tolhurst, K.G.; Bennett, L.T. Repeated prescribed fires decrease stocks and change attributes of coarse woody debris in a temperate eucalypt forest. Ecol. Appl. 2014, 24, 976-989. [CrossRef] [PubMed]

38. Bennett, L.T.; Aponte, C.; Tolhurst, K.G.; Löw, M.; Baker, T.G. Decreases in tree-based carbon stocks associated with repeated prescribed fires in a temperate mixed-species eucalypt forest. For. Ecol. Manag. 2013, 306, 243-255. [CrossRef]

39. Tran, B.N.; Tanase, M.A.; Bennett, L.T.; Aponte, C. High-severity wildfires in temperate Australian forests have increased in extent and aggregation in recent decades. PLOS ONE 2020, 15, e0242484. [CrossRef] [PubMed]

40. Tran, B.N.; Tanase, M.A.; Bennett, L.T.; Aponte, C. Evaluation of spectral indices for assessing fire severity in Australian temperate forests. Remote Sens. 2018, 10, 1680. [CrossRef]

41. Karna, Y.K.; Penman, T.D.; Aponte, C.; Hinko-Najera, N.; Bennett, L.T. Persistent changes in the horizontal and vertical canopy structure of fire-tolerant forests after severe fire as quantified using multi-temporal airborne lidar data. For. Ecol. Manag. 2020, 472, 118255. [CrossRef]

42. Karna, Y.K.; Penman, T.D.; Aponte, C.; Bennett, L.T. Assessing legacy effects of wildfires on the crown structure of fire-tolerant eucalypt trees using airborne lidar data. Remote Sens. 2019, 11, 2433. [CrossRef]

43. Axelson, J.; Hawkes, B.; van Akker, L.; Alfaro, R. Stand dynamics and the mountain pine beetle-thirty years of forest change in Waterton Lakes National Park, Alberta, Canada. Can. J. For. Res. 2018, 48, 1159-1170. [CrossRef]

44. Axelson, J.; Alfaro, R.; Hawkes, B. Influence of fire and mountain pine beetle on the dynamics of lodgepole pine stands in British Columbia, Canada. For. Ecol. Manag. 2009, 257, 1874-1882. [CrossRef]

45. Axelson, J.; Smith, D.; Daniels, L.; Alfaro, R. Multicentury reconstruction of western spruce budworm outbreaks in central British Columbia, Canada. For. Ecol. Manag. 2015, 335, 235-248. [CrossRef]

46. Axelson, J.; Bast, A.; Alfaro, R.; Smith, D.; Gärtner, H. Variation in wood anatomical structure of Douglas-fir defoliated by the western spruce budworm: A case study in the coastal-transitional zone of British Columbia, Canada. Trees 2014, 28, 1837-1846. [CrossRef]

47. Axelson, J.; Battles, J.; Buloan, B.; Cluck, D.; Cousins, S.; Cox, L.; Estes, B.; Fettig, C.; Hefty, A.; Hishinuma, S.; et al. The California Tree Mortality Data Network-Enhanced Communication and Collaboration among Scientists \& Stakeholders. Calif. Agric. 2019, $73,55-62$. 
48. Axelson, J.; Battles, J.; Das, A.; van Mantgem, P. Coming to terms with the new normal: Forest resilience and mortality in the Sierra Nevada (Invited). Fremontia 2019, 46, 50-56.

49. Barreiro, S.; Tomé, M. SIMPLOT: Simulating the impacts of fire severity on sustainability of eucalyptus forests in Portugal. Ecol. Indic. 2011, 11, 36-45. [CrossRef]

50. Barreiro, S.; Tomé, M. Analysis of the Impact of the Use of Eucalyptus Biomass for Energy on Wood Availability for Eucalyptus Forest in Portugal: A Simulation Study. Ecol. Soc. 2012, 17, 14. [CrossRef]

51. Barreiro, S.; Rua, J.; Tomé, M. StandsSIM-MD: A management driven forest SIMulator. For. Syst. 2016, 25, eRC07. [CrossRef]

52. Barreiro, S.; Schelhaas, M.-J.; Kändler, G.; Antón-Fernández, C.; Colin, A.; Bontemps, J.-D.; Alberdi, I.; Condés, S.; Dumitru, M.; Ferezliev, A.; et al. Overview of methods and tools for evaluating future woody biomass availability in European countries. Ann. For. Sci. 2016, 73, 823-837. [CrossRef]

53. Barreiro, S.; Tomé, M. Projection Systems in Europe and North America: Concepts and Approaches. In Forest Inventory-Based Projection Systems for Wood and Biomass Availability; Springer: Cham, Switzerland, 2017; pp. 25-47.

54. Boyer, E.; Goodale, C.L.; Jaworski, N.A.; Howarth, R. Anthropogenic nitrogen sources and relationships to riverine nitrogen export in the northeastern U.S.A. Biogeochemistry 2002, 57-58, 137-169. [CrossRef]

55. Campbell, J.; Rustad, L.; Boyer, E.; Christopher, S.; Driscoll, C.; Fernandez, I.; Groffman, P.; Houle, D.; Kiekbusch, J.; Magill, A.; et al. Consequences of Climate Change for Biogeochemical Cycling in Forests of Northeastern North America. Can. J. For. Res. 2009, 39, 264-284. [CrossRef]

56. Risch, M.R.; DeWild, J.F.; Gay, D.A.; Zhang, L.; Boyer, E.W.; Krabbenhoft, D.P. Atmospheric mercury deposition to forests in the eastern USA. Environ. Pollut. 2017, 228, 8-18. [CrossRef] [PubMed]

57. Sebestyen, S.D.; Boyer, E.W.; Shanley, J.B. Responses of stream nitrate and DOC loadings to hydrological forcing and climate change in an upland forest of the northeastern United States. J. Geophys. Res. Biogeosci. 2009, 114, 2156-2202. [CrossRef]

58. Clark, D.A.; Clark, D.B. Life History Diversity of Canopy and Emergent Trees in a Neotropical Rain Forest. Ecol. Monogr. 1992, 62, 315-344. [CrossRef]

59. Clark, D. Tropical rain forest tree growth and atmospheric carbon dynamics linked to interannual temperature variation during 1984-2000. Proc. Natl. Acad. Sci. USA 2003, 100, 5852-5857. [CrossRef] [PubMed]

60. Clark, D.A.; Clark, D.B. Assessing Tropical Forests' Climatic Sensitivities with Long-term Data. Biotropica 2011, 43, 31-40. [CrossRef]

61. Clark, D.; Clark, D.; Oberbauer, S. Field-quantified responses of tropical rainforest aboveground productivity to increasing $\mathrm{CO}_{2}$ and climatic stress, 1997-2009. J. Geophys. Res. 2013, 118, 783-794. [CrossRef]

62. Clark, D.; Asao, S.; Fisher, R.; Reed, S.; Reich, P.B.; Ryan, M.; Wood, T.; Yang, X. Reviews and syntheses: Field data to benchmark the carbon cycle models for tropical forests. Biogeosciences 2017, 14, 4663-4690. [CrossRef]

63. Crowley, M.A.; Cardille, J.A. Remote sensing's recent and future contributions to landscape ecology. Curr. Landsc. Ecol. Rep. 2020, 5, 45-57. [CrossRef]

64. Crowley, M.A.; Cardille, J.A.; White, J.C.; Wulder, M.A. Multi-sensor, multi-scale, Bayesian data synthesis for mapping within-year wildfire progression. Remote Sens. Lett. 2019, 10, 302-311. [CrossRef]

65. Crowley, M.A.; Cardille, J.A.; White, J.C.; Wulder, M.A. Generating intra-year metrics of wildfire progression using multiple open-access satellite data streams. Remote Sens. Environ. 2019, 232, 111295. [CrossRef]

66. Crowley, M.A.; Hartter, J.; Congalton, R.G.; Hamilton, L.C.; Christoffersen, N.D. Characterizing non-industrial private forest landowners' forest management engagement and advice sources. Soc. Nat. Resour. 2019, 32, 204-221. [CrossRef]

67. Graciano, C.; Guiamet, J.J.; Goya, J.F. Fertilization and water stress interactions in young Eucalyptus grandis plants. Can. J. For. Res. 2006, 36, 1028-1034. [CrossRef]

68. Faustino, L.; Bulfe, N.; Pinazo, M.; Monteoliva, S.; Graciano, C. Dry weight partitioning and hydraulic traits in young Pinus taeda trees fertilized with nitrogen and phosphorus in a subtropical area. Tree Physiol. 2013, 33, 241-251. [CrossRef]

69. Gortari, F.; Guiamet, J.J.; Cortizo, S.C.; Graciano, C. Poplar leaf rust reduces dry mass accumulation and internal nitrogen recycling more markedly under low soil nitrogen availability, and decreases growth in the following spring. Tree Physiol. 2019, 39, 19-30. [CrossRef]

70. Gortari, F.; Guiamet, J.J.; Graciano, C. Plant-pathogen interactions: Leaf physiology alterations in poplars infected with rust (Melampsora medusae). Tree Physiol. 2018, 38, 925-935. [CrossRef]

71. Moretti, A.P.; Olguin, F.Y.; Pinazo, M.A.; Graciano, C. Water and light stresses drive acclimation during the establishment of a timber tree under different intensities of rainforest canopy coverage. CERNE 2019, 25, 93-104. [CrossRef]

72. Heinsch, F.A.; Sikkink, P.G.; Smith, H.Y.; Retzlaff, M.L. Characterizing Fire Behavior from Laboratory Burns of Multi-Aged, MixedConifer Masticated Fuels in the Western United States; RMRS-RP-107; Rocky Mountain Research Station, Forest Service, U.S. Department of Agriculture: Fort Collins, CO, USA, 2018; 23p.

73. Heinsch, F.A.; Andrews, P.L.; Tirmenstein, D. How to Generate and Interpret Fire Characteristics Charts for the U.S. Fire Danger Rating System; General Technical Report; RMRS-GTR-363; Rocky Mountain Research Station, Forest Service, U.S. Department of Agriculture: Fort Collins, CO, USA, 2017; 62p.

74. Riley, K.L.; Abatzoglou, J.T.; Grenfell, I.C.; Klene, A.E.; Heinsch, F.A. The relationship of large fire occurrence with drought and fire danger indices in the western USA, 1984-2008: The role of temporal scale. Int. J. Wildland Fire 2013, 22, 894-909. [CrossRef] 
75. Jones, N.; Filos, I.; Fates, E.; Dimitrakopoulos, P.G. Exploring perceptions on participatory management of NATURA 2000 forest sites in Greece. For. Policy Econ. 2015, 56, 1-8. [CrossRef]

76. Jones, N.; Malesios, C.; Kantartzis, A.; Dimitrakopoulos, P.G. The role of location and social impacts of Protected Areas on subjective wellbeing. Environ. Res. Lett. 2020, 15, 114030. [CrossRef]

77. Jones, N.; Graziano, M.; Dimitrakopoulos, P.G. Social impacts of European Protected areas and policy recommendations. Environ. Sci. Policy 2020, 112, 134-140. [CrossRef] [PubMed]

78. Jones, N.; Clark, J.R.A. Social capital and the public acceptability of climate change adaptation policies: A case study in Romney Marsh, UK. Clim. Change 2014, 123, 133-145. [CrossRef]

79. Kaiser, B.; Roumasset, J. Valuing indirect ecosystem services: The case of tropical watersheds. Environ. Dev. Econ. 2002, 7, 701-714. [CrossRef]

80. Kaiser, B.A. Watershed Conservation in the Long Run. Ecosystems 2014, 17, 698-719. [CrossRef]

81. Kaiser, B.A.; Pitafi, B.A.K.; Roumasset, J.A.; Burnett, K.M. The Economic Value of Watershed Conservation. Coast. Watershed Manag. 2008, 299-329.

82. Burnett, K.; Kaiser, B.; Roumasset, J. Economic lessons from control efforts for an invasive species: Miconia calvescens in Hawaii. J. For. Econ. 2007, 13, 151-167. [CrossRef]

83. Kaiser, B.A. The national environmental policy act's influence on USDA forest service decision-making, 1974-1996. J. For. Econ. 2006, 12, 109-130. [CrossRef]

84. Freeman, J.; Kobziar, L.N.; Rose, E.W.; Cropper, W. An evaluation of the historical fire regime concept in conservation. Biol. Conserv. 2017, 31, 976-985. [CrossRef]

85. Pingree, M.; Kobziar, L.N. The myth of the biological threshold: A review of biological responses to soil heating associated with wildland fire. For. Ecol. Manag. 2019, 432, 1022-1029. [CrossRef]

86. McLauchlan, K.; Higuera, P.E.; Miesel, J.; Rogers, B.M.; Schweitzer, J.; Shuman, J.K.; Tepley, A.J.; Morgan, V.J.; Veblen, T.T.; Adalsteinsson, S.A.; et al. Fire as a fundamental ecological process: Research advances and frontiers. J. Ecol. 2020, 108, 2047-2069. [CrossRef]

87. Kobziar, L.N.; Pingree, M.R.A.; Larson, H.; Dreaden, T.J.; Green, S.; Smith, J.A. Pyroaerobiology: The aerosolization and transport of viable microbial life by wildland fire. Ecosphere 2018, 9, e02507. [CrossRef]

88. Kobziar, L.N.; Thompson, G.R. Wildfire smoke, a potential infectious agent. Science 2020, 370, 1408-1410. [CrossRef]

89. Smith, J.W.; Leahy, J.E.; Anderson, D.H.; Davenport, M.A. Community/Agency Trust: A Measurement Instrument. Soc. Nat. Resour. 2013, 26, 472-477. [CrossRef]

90. Mann, M.; Leahy, J. Social capital in an outdoor recreation context. Environ. Manag. 2010, 45, 363-376. [CrossRef]

91. Marciano, J.A.; Lilieholm, R.J.; Teisl, M.F.; Leahy, J.E.; Neupane, B. Factors affecting public support for forest-based biorefineries: A comparison of mill towns and the general public in Maine, USA. Energy Policy 2014, 75, 301-311. [CrossRef]

92. Johnson, E.S.; Bell, K.P.; Leahy, J.E. Managing the science-policy boundary: Implications for river restoration. J. Environ. Stud. Sci. 2018, 8, 281-289. [CrossRef]

93. Guo, T.; Leahy, J.; Huff, E.S.; Danks, C.; Adams, M. A Social Network Analysis of a Regional Automated Wood Pellet Heating Industry in Pursuing Homeowner Satisfaction. For. Prod. J. 2018, 68, 182-190. [CrossRef]

94. Juerges, N.; Leahy, J.; Newig, J. Actor perceptions of polycentricity in wind power governance. Environ. Policy Gov. 2018, 28, 383-394. [CrossRef]

95. Liu, H.; Gleason, S.M.; Hao, G.; Hua, L.; He, P.; Goldstein, G.; Ye, Q. Hydraulic traits are coordinated with maximum plant height at the global scale. Sci. Adv. 2019, 5, eaav1332. [CrossRef]

96. Zhu, S.-D.; Liu, H.; Xu, Q.-Y.; Cao, K.-F.; Ye, Q. Are leaves more vulnerable to cavitation than branches? Funct. Ecol. 2016, 30, 1740-1744. [CrossRef]

97. Liu, H.; Lundgren, M.R.; Freckleton, R.P.; Xu, Q.; Ye, Q. Uncovering the spatio-temporal drivers of species trait variances: A case study of Magnoliaceae in China. J. Biogeogr. 2016, 43, 1179-1191. [CrossRef]

98. Liu, H.; Xu, Q.; He, P.; Santiago, L.S.; Yang, K.; Ye, Q. Strong phylogenetic signals and phylogenetic niche conservatism in ecophysiological traits across divergent lineages of Magnoliaceae. Sci. Rep. 2015, 5, 12246. [CrossRef]

99. Liu, H.; Zhu, L.; Xu, Q.; Lundgren, M.R.; Yang, K.; Zhao, P.; Ye, Q. Ecophysiological responses of two closely related Magnoliaceae genera to seasonal changes in subtropical China. J. Plant Ecol. 2018, 11, 434-444. [CrossRef]

100. Liu, H.; Xu, Q.; Lundgren, M.; Ye, Q. Different water relations between flowering and leaf periods: A case study in flower-beforeleaf-emergence Magnolia species. Funct. Plant Biol. 2017, 44, 1098-1110. [CrossRef]

101. Xu, Q.Y.; Liu, H.; Ye, Q. Intraspecific variability of ecophysiological traits of four Magnoliaceae species growing in two climatic regions in China. Plant Ecol. 2017, 218, 407-415. [CrossRef]

102. Liu, J.; Zhang, D.; Zhou, G.; Faivre-Vuillin, B.; Deng, Q.; Wang, C. $\mathrm{CO}_{2}$ enrichment increases nutrient leaching from model forest ecosystems in subtropical China. Biogeosci. Discuss. 2008, 5, 1783-1795. [CrossRef]

103. Liu, J.; Zhou, G.; Zhang, D.; Xu, Z.; Duan, H.; Deng, Q.; Zhao, L. Carbon dynamics in subtropical forest soil: Effects of atmospheric carbon dioxide enrichment and nitrogen addition. J. Soils Sediments 2010, 10, 730-738. [CrossRef]

104. Liu, J.; Xu, Z.; Zhang, D.; Zhou, G.; Deng, Q.; Duan, H.; Zhao, L.; Wang, C. Effects of Carbon Dioxide Enrichment and Nitrogen Addition on Inorganic Carbon Leaching in Subtropical Model Forest Ecosystems. Ecosystems 2011, 14, 683-697. [CrossRef] 
105. Liu, J.; Huang, W.; Zhou, G.; Zhang, D.; Liu, S.; Li, Y. Nitrogen to phosphorus ratios of tree species in response to elevated carbon dioxide and nitrogen addition in subtropical forests. Glob. Change Biol. 2013, 19, 208-216. [CrossRef] [PubMed]

106. Liu, J.; Li, Y.; Xu, Y.; Liu, S.; Huang, W.; Fang, X.; Yin, G. Phosphorus uptake in four tree species under nitrogen addition in subtropical China. Environ. Sci. Pollut. Res. 2017, 24, 20005-20014. [CrossRef]

107. Huang, J.; Liu, J.; Zhang, W.; Cai, X.; Liu, L.; Zheng, M.; Mo, J. Effects of urbanization on plant phosphorus availability in broadleaf and needleleaf subtropical forests. Sci. Total Environ. 2019, 684, 50-57. [CrossRef]

108. Liu, W.; Hsu, K. An Economic Analysis of Forest Carbon Payment Policy. Age Econ. 2017, 59, 1-48.

109. Liu, W.-Y.; Chuang, C. Preferences of Tourists for the Service Quality of Taichung Calligraphy Greenway in Taiwan. Forests 2018, 9, 462. [CrossRef]

110. Lin, J.-C.; Chiu, C.-M.; Lin, Y.-J.; Liu, W.-Y. Thinning Effects on Biomass and Carbon Stock for Young Taiwania Plantations. Sci. Rep. 2018, 8, 3070. [CrossRef] [PubMed]

111. Chiou, C.-R.; Lin, J.-C.; Liu, W.-Y. The Carbon Benefit of Thinned Wood for Bioenergy in Taiwan. Forests 2019, 10, 255. [CrossRef]

112. Liu, W.-Y.; Lin, C.-C. Spatial forest resource planning using a cultural algorithm with problem-specific information. Environ. Model. Softw. 2015, 71, 126-137. [CrossRef]

113. Lu, M.; Krutovsky, K.V.; Nelson, C.D.; Koralewski, T.E.; Byram, T.D.; Loopstra, C.A. Exome genotyping, linkage disequilibrium and population structure in loblolly pine (Pinus taeda L.). BMC Genom. 2016, 17, 730. [CrossRef]

114. Lu, M.; Krutovsky, K.V.; Nelson, C.D.; West, J.B.; Reilly, N.A.; Loopstra, C.A. Association genetics of growth and adaptive traits in loblolly pine (Pinus taeda L.) using whole-exome-discovered polymorphisms. Tree Genet. Genomes 2017, 13, 57. [CrossRef]

115. Lu, M.; Seeve, C.M.; Loopstra, C.A.; Krutovsky, K.V. Exploring the genetic basis of gene transcript abundance and metabolite levels in loblolly pine (Pinus taeda L.) using association mapping and network construction. BMC Genet. 2018, 19, 100. [CrossRef]

116. Lu, M.; Loopstra, C.A.; Krutovsky, K.V. Detecting the genetic basis of local adaptation in loblolly pine (Pinus taeda L.) using whole exome-wide genotyping and an integrative landscape genomics analysis approach. Ecol. Evol. 2019, 9, 6798-6809. [CrossRef]

117. Lucardi, R.D.; Wallace, L.E.; Ervin, G.N. Invasion success in Cogongrass (Imperata cylindrica): A population genetic approach exploring genetic diversity and historical introductions. Invasive Plant Sci. Manag. 2014, 7, 59-75. [CrossRef]

118. Whitney, T.D.; Gandhi, K.J.; Hamrick, J.L.; Lucardi, R.D. Extant population genetic variation and structure of eastern white pine (Pinus strobus L.) in the Southern Appalachians. Tree Genet. Genomes 2019, 15, 74. [CrossRef]

119. Zomlefer, W.B.; Comer, J.R.; Lucardi, R.D.; Hamrick, J.L.; Allison, J.R. Distribution and genetic diversity of the rare plant Veratrum woodii (Liliales: Melanthiaceae) in Georgia: A preliminary study with AFLP fingerprint data. Syst. Bot. 2018, 43, 858-869. [CrossRef]

120. Lucardi, R.D.; Cunard, C.E.; Hughes, S.C.; Burgess, K.S.; Reed, J.N.; Whitehurst, L.E.; Worthy, S.J.; Marsico, T.D. An initial industrial flora: A framework for botanical research in cooperation with industry for biodiversity conservation. PLoS ONE 2020, 15, e0230729. [CrossRef]

121. Lucardi, R.D.; Bellis, E.S.; Cunard, C.E.; Gravesande, J.K.; Hughes, S.C.; Whitehurst, L.E.; Marsico, T.D. Seeds attached to refrigerated shipping containers represent a substantial risk of nonnative plant species introduction and establishment. Sci. Rep. 2020, 10, 1-10. [CrossRef] [PubMed]

122. Wulder, M.A.; White, J.C.; Cranny, M.; Hall, R.J.; Luther, J.E.; Beaudoin, A.; Goodenough, D.G.; Dechka, J.A. Monitoring Canada's forests. Part 1: Completion of the EOSD land cover project. Can. J. Remote Sens. 2008, 34, 549-562. [CrossRef]

123. Luther, J.E.; Carroll, A.L. Development of an Index of Balsam Fir Vigor by Foliar Spectral Reflectance. Remote Sens. Environ. 1999, 69, 241-252. [CrossRef]

124. Labrecque, S.; Fournier, R.A.; Luther, J.E.; Piercey, D. A comparison of four methods to map biomass from Landsat-TM and inventory data in western Newfoundland. For. Ecol. Manag. 2006, 226, 129-144. [CrossRef]

125. Luther, J.E.; Skinner, R.; Fournier, R.A.; van Lier, O.R.; Bowers, W.W.; Coté, J.-F.; Hopkinson, C.; Moulton, T. Predicting wood quantity and quality attributes of balsam fir and black spruce using airborne laser scanner data. For. Int. J. For. Res. 2014, 87, 313-326. [CrossRef]

126. Van Lier, O.R.; Luther, J.E.; Leckie, D.G.; Bowers, W.W. Development of large-area land cover and forest change indicators using multi-sensor Landsat imagery: Application to the Humber River Basin, Canada. Int. J. Appl. Earth Obs. Geoinf. 2011, 13, 819-829. [CrossRef]

127. Luther, J.E.; Fournier, R.A.; van Lier, O.R.; Bujold, M. Extending ALS-Based Mapping of Forest Attributes with Medium Resolution Satellite and Environmental Data. Remote Sens. 2019, 11, 1092. [CrossRef]

128. Macinnis- $\mathrm{Ng}, \mathrm{C}$.; Schwendenmann, L. Litterfall, carbon and nitrogen cycling in a southern hemisphere conifer forest dominated by kauri (Agathis australis) during drought. Plant Ecol. 2015, 216, 247-262. [CrossRef]

129. Kaplick, J.; Clearwater, M.J.; Macinnis-Ng, C. Comparative water relations of co-occurring trees in a mixed podocarp-broadleaf forest. J. Plant Ecol. 2019, 12, 163-175. [CrossRef]

130. Cranston, B.M.; Powers, B.F.; Macinnis-Ng, C. Inexpensive throughfall exclusion experiment for single large trees. Appl. Plant Sci. 2020, 8, e11325. [CrossRef]

131. Macinnis-Ng, C.; Wyse, S.V.; Webb, T.; Taylor, D.; Schwendenmann, L. Sustained carbon uptake in a mixed age southern conifer forest. Trees 2017, 31, 967-980. [CrossRef] 
132. O’Brien, M.J.; Engelbrecht, B.M.; Joswig, J.; Pereyra, G.; Schuldt, B.; Jansen, S.; Kattge, J.; Landhäusser, S.M.; Levick, S.R.; Preisler, Y.; et al. A synthesis of tree functional traits related to drought-induced mortality in forests across climatic zones. J. Appl. Ecol. 2017, 54, 1669-1686. [CrossRef]

133. Hartmann, H.; Schuldt, B.; Sanders, T.G.; Macinnis-Ng, C.; Boehmer, H.J.; Allen, C.D.; Bolte, A.; Crowther, T.W.; Hansen, M.C.; Medlyn, B.E.; et al. Monitoring global tree mortality patterns and trends. Report from the VW symposium 'Crossing scales and disciplines to identify global trends of tree mortality as indicators of forest health'. New Phytol. 2018, 217, 984-987. [CrossRef]

134. Pettorelli, N.; Schulte to Bühne, H.; Tulloch, A.; Dubois, G.; Macinnis-Ng, C.; Queirós, A.M.; Keith, D.A.; Wegmann, M.; Schrodt, F.; Stellmes, M.; et al. Satellite remote sensing of ecosystem functions: Opportunities, challenges and way forward. Remote Sens. Ecol. Conserv. 2018, 4, 71-93. [CrossRef]

135. Chambers, C.; McComb, B.; Tappeiner, I. John Breeding Bird Responses to Three Silvicultural Treatments in the Oregon Coast Range. Ecol. Appl. 1999, 9, 171-185. [CrossRef]

136. McGarigal, K.; McComb, W.C. Relationships between Landscape Structure and Breeding Birds in the Oregon Coast Range. Ecol. Monogr. 1995, 65, 235-260. [CrossRef]

137. Martin, K.J.; McComb, B.C. Amphibian Habitat Associations at Patch and Landscape Scales in the Central Oregon Coast Range. J. Wildl. Manag. 2003, 67, 672-683. [CrossRef]

138. Martin, K.J.; McComb, B. Small Mammal Habitat Associations at Patch and Landscape Scales in Oregon. For. Sci. 2002, 48, 255-264.

139. McComb, B.; Spies, T.A.; Olsen, K. Sustaining Biodiversity in the Oregon Coast Range: Potential effects of Forest Policies in a Multi-ownership Province. Ecol. Soc. 2007, 12, 29. [CrossRef]

140. Spies, T.A.; McComb, B.C.; Kennedy, R.S.H.; McGrath, M.T.; Olsen, K.; Pabst, R.J. Potential effects of forest policies on terrestrial biodiversity in a multi-ownership province. Ecol. Appl. Publ. Ecol. Soc. Am. 2007, 17, 48-65. [CrossRef]

141. Spies, T.A.; Johnson, K.N.; Burnett, K.M.; Ohmann, J.L.; McComb, B.C.; Reeves, G.H.; Bettinger, P.; Kline, J.D.; Garber-Yonts, B. Cumulative ecological and socioeconomic effects of forest policies in coastal Oregon. Ecol. Appl. Publ. Ecol. Soc. Am. 2007, 17, 5-17. [CrossRef]

142. McComb, B.C. Wildlife Habitat Management: Concepts and Applications in Forestry, Second Edition; CRC Press: Boca Raton, FL, USA, 2015; ISBN 978-1-4398-7856-9.

143. McComb, B.; Zuckerberg, B.; Vesely, D.; Jordan, C. Monitoring Animal Populations and Their Habitats: A Practitioner's Guide; CRC Press: Boca Raton, FL, USA, 2010; ISBN 978-1-4200-7055-2.

144. Lo Monaco, A.; Balletti, F.; Pelosi, C. Wood in cultural Heritage. Properties and conservation of Historical wooden artefacts. Eur. J. Sci. Theol. 2018, 14, 161-171.

145. Capobianco, G.; Calienno, L.; Pelosi, C.; Scacchi, M.; Bonifazi, G.; Agresti, G.; Picchio, R.; Santamaria, U.; Serranti, S.; Lo Monaco, A. Protective behaviour monitoring on wood photo-degradation by spectroscopic techniques coupled with chemometrics. Spectrochim. Acta. Part A Mol. Biomol. Spectrosc. 2017, 172, 34-42. [CrossRef] [PubMed]

146. Picchio, R.; Venanzi, R.; Latterini, F.; Marchi, E.; Laschi, A.; Lo Monaco, A. Corsican pine (Pinus laricio Poiret) stand management: Medium and long lasting effects of thinning on biomass growth. Forests 2018, 9, 257. [CrossRef]

147. Picchio, R.; Tavankar, F.; Nikooy, M.; Pignatti, G.; Venanzi, R.; Lo Monaco, A. Morphology, growth and architecture response of beech (Fagus orientalis Lipsky) and maple tree (Acer velutinum Boiss.) seedlings to soil compaction stress caused by mechanized logging operations. Forests 2019, 10, 771. [CrossRef]

148. Behjou, F.K.; Lo Monaco, A.; Tavankar, F.; Venanzi, R.; Nikooy, M.; Picchio, R. Coarse woody debris variability as result of human accessibility to forest. Forests 2018, 9, 509. [CrossRef]

149. Lo Monaco, A.; Luziatelli, G.; Latterini, F.; Tavankar, F.; Picchio, R. Structure and dynamics of deadwood in pine and oak stands and their role in $\mathrm{CO}_{2}$ sequestration in lowland forests of Central Italy. Forests 2020, 11, 253. [CrossRef]

150. Lo Monaco, A.; Pelosi, C.; Agresti, G.; Picchio, R.; Rubino, G. Influence of thermal treatment on selected properties of chestnut wood and full range of its visual features. Drewno 2020, 63, 5-24.

151. Jourgholami, M.; Karami, S.; Tavankar, F.; Lo Monaco, A.; Picchio, R. Effects of Slope Gradient on Runoff and Sediment Yield on Machine-Induced Compacted Soil in Temperate Forests. Forests 2021, 12, 49. [CrossRef]

152. Esquivel-Muelbert, A.; Baker, T.R.; Dexter, K.G.; Lewis, S.L.; Ter Steege, H.; Lopez-Gonzalez, G.; Monteagudo Mendoza, A.; Brienen, R.; Feldpausch, T.R.; Pitman, N.; et al. Seasonal drought limits tree species across the Neotropics. Ecography 2017, 40, 618-629. [CrossRef]

153. Esquivel-Muelbert, A.; Galbraith, D.; Dexter, K.G.; Baker, T.R.; Lewis, S.L.; Meir, P.; Rowland, L.; da Costa, A.C.L.; Nepstad, D.; Phillips, O.L. Biogeographic distributions of neotropical trees reflect their directly measured drought tolerances. Sci. Rep. 2017, 7, 8334. [CrossRef] [PubMed]

154. Esquivel-Muelbert, A.; Baker, T.R.; Dexter, K.G.; Lewis, S.L.; Brienen, R.J.; Feldpausch, T.R.; Lloyd, J.; Monteagudo-Mendoza, A.; Arroyo, L.; Álvarez-Dávila, E.; et al. Compositional response of Amazon forests to climate change. Glob. Change Biol. 2019, 25, 39-56. [CrossRef]

155. Esquivel-Muelbert, A.; Phillips, O.L.; Brienen, R.J.; Fauset, S.; Sullivan, M.J.; Baker, T.R.; Chao, K.J.; Feldpausch, T.R.; Gloor, E.; Higuchi, N.; et al. Tree mode of death and mortality risk factors across Amazon forests. Nat. Commun. 2020, 11, 5515. [CrossRef]

156. Gora, E.M.; Esquivel-Muelbert, A. Implications of size-dependent tree mortality for tropical forest carbon dynamics. Nat. Plants 2021, 7, 384-391. [CrossRef] [PubMed] 
157. Wu, W.; Zhou, R.-C.; Ni, G.-Y.; Shen, H.; Ge, X.-J. Is a new invasive herb emerging? Molecular confirmation and preliminary evaluation of natural hybridization between the invasive Sphagneticola trilobata (Asteraceae) and its native congener S. calendulacea in South China. Biol. Invasions 2013, 15, 75-88. [CrossRef]

158. Ni, G.; Schaffner, U.; Peng, S.-L.; Callaway, R. Acroptilon repens, an Asian invader, has stronger competitive effects on species from America than species from its native range. Biol. Invasions 2010, 12, 3653-3663. [CrossRef]

159. Xiao, S.; Ni, G.; Callaway, R. Models of Experimentally Derived Competitive Effects Predict Biogeographical Differences in the Abundance of Invasive and Native Plant Species. PLoS ONE 2013, 8, e78625. [CrossRef] [PubMed]

160. Ni, G.; Zhao, P.; Wu, W.; Xiankai, L.; Zhao, X.-H.; Zhu, L.-W.; Niu, J. A hybrid of the invasive plant Sphagneticola trilobata has similar competitive ability but different response to nitrogen deposition compared to parent. Ecol. Res. 2014, 29, 331-339. [CrossRef]

161. Niu, S.; Luo, Y.; Dieze, M.; Keenan, T.; Li, J.; Shi, Z.; Chapin, T., III. The role of data assimilation in predictive Ecology. Ecosphere 2014, 5, 1-16. [CrossRef]

162. Niu, S.; Fu, Z.; Luo, Y.; Stoy, P.C.; Keenan, T.F.; Poulter, B.; Zhang, L.; Piao, S.; Zhou, X.; Zheng, H.; et al. Interannual variability of ecosystem carbon exchange: From observation to prediction. Glob. Ecol. Biogeogr. 2017, 26, 1225-1237. [CrossRef]

163. Niu, S.; Classen, A.T.; Dukes, J.S.; Kardol, P.; Liu, L.; Luo, Y.; Rustad, L.; Sun, J.; Tang, J.; Templer, P.H.; et al. Global patterns and substrate-based mechanisms of the terrestrial nitrogen cycle. Ecol. Lett. 2016, 19, 697-709. [CrossRef]

164. Niu, S.; Classen, A.; Luo, Y. Functional traits along a transect. Funct. Ecol. 2018, 32, 4-9. [CrossRef]

165. Zhang, F.; Quan, Q.; Ma, F.; Tian, D.; Zhou, Q.; Niu, S. Differential responses of ecosystem carbon flux components to experimental precipitation gradient in an alpine meadow. Funct. Ecol. 2019, 1365-2435. [CrossRef]

166. Nolan, R.H.; Gauthey, A.; Losso, A.; Medlyn, B.E.; Smith, R.; Chhajed, S.S.; Fuller, K.; Song, M.; Li, X.; Beaumont, L.J.; et al Hydraulic failure and tree size linked with canopy die-back in eucalypt forest during extreme drought. New Phytol. 2021, 230, 1354-1365. [CrossRef]

167. Nolan, R.H.; Mitchell, P.J.; Bradstock, R.A.; Lane, P.N.J. Structural adjustments in resprouting trees drive differences in post-fire transpiration. Tree Physiol. 2014, 34, 123-136. [CrossRef]

168. Nolan, R.H.; Blackman, C.J.; De Dios, V.R.; Choat, B.; Medlyn, B.E.; Li, X.; Bradstock, R.A.; Boer, M.M. Linking forest flammability and plant vulnerability to drought. Forests 2020, 11, 779. [CrossRef]

169. Nolan, R.H.; Hedo, J.; Arteaga, C.; Sugai, T.; Resco de Dios, V. Physiological drought responses improve predictions of live fuel moisture dynamics in a Mediterranean forest. Agric. For. Meteorol. 2018, 263, 417-427. [CrossRef]

170. Nolan, R.H.; Boer, M.M.; Collins, L.; Resco de Dios, V.; Clarke, H.G.; Jenkins, M.; Kenny, B.; Bradstock, R.A. Causes and consequences of eastern Australia's 2019-20 season of mega-fires. Glob. Change Biol. 2020, 26, 1039-1041. [CrossRef] [PubMed]

171. Nolan, R.H.; Boer, M.M.; Resco de Dios, V.; Caccamo, G.; Bradstock, R.A. Large-scale, dynamic transformations in fuel moisture drive wildfire activity across southeastern Australia. Geophys. Res. Lett. 2016, 43, 4229-4238. [CrossRef]

172. Paoletti, E. Impact of ozone on Mediterranean forests: A review. Environ. Pollut. 2006, 144, 463-474. [CrossRef]

173. Li, P.; Feng, Z.; Catalayud, V.; Yuan, X.; Xu, Y.; Paoletti, E. A meta-analysis on growth, physiological, and biochemical responses of woody species to ground-level ozone highlights the role of plant functional types. Plant Cell Environ. 2017, 40, 2369-2380. [CrossRef]

174. Paoletti, E.; Materassi, A.; Fasano, G.; Hoshika, Y.; Carriero, G.; Silaghi, D.; Badea, O. A new-generation 3D ozone FACE (Free Air Controlled Exposure). Sci. Total Environ. 2016, 575, 1407-1414. [CrossRef]

175. Paoletti, E.; Alivernini, A.; Anav, A.; Badea, O.; Carrari, E.; Chivulescu, S.; Conte, A.; Ciriani, M.L.; Dalstein-Richier, L.; De Marco, A.; et al. Toward stomatal-flux based forest protection against ozone: The MOTTLES approach. Sci. Total Environ. 2019, 691, 516-527. [CrossRef]

176. Bytnerowicz, A.; Omasa, K.; Paoletti, E. Integrated Effects of Air Pollution and Climate Change on Forests: A Northern Hemisphere Perspective. Environ. Pollut. 2007, 147, 438-445. [CrossRef]

177. Hoshika, Y.; Katata, G.; Deushi, M.; Watanabe, M.; Koike, T.; Paoletti, E. Ozone-induced stomatal sluggishness changes carbon and water balance of temperate deciduous forests. Nat. Sci. Rep. 2015, 5, 9871. [CrossRef] [PubMed]

178. Poland, T.; Mccullough, D. Emerald Ash Borer: Invasion of the urban forest and the threat to North America's Ash resource. J. For. 2006, 104, 118-124.

179. Poland, T.; Mccullough, D. Comparison of Trap Types and Colors for Capturing Emerald Ash Borer Adults at Different Population Densities. Environ. Entomol. 2014, 43, 157-170. [CrossRef] [PubMed]

180. Poland, T.; Chen, Y.; Koch, J.; Pureswaran, D. Review of the emerald ash borer (Coleoptera: Buprestidae), life history, mating behaviours, host plant selection, and host resistance. Can. Entomol. 2015, 147, 252-262. [CrossRef]

181. Poland, T.M.; Haack, R.A.; Petrice, T.R.; Miller, D.L.; Bauer, L.S.; Gao, R. Field evaluations of systemic insecticides for control of Anoplophora glabripennis (Coleoptera: Cerambycidae) in China. J. Econ. Entomol. 2006, 99, 383-392. [CrossRef] [PubMed]

182. Poland, T.; Rassati, D. Improved biosecurity surveillance of non-native forest insects: A review of current methods. J. Pest Sci. 2018, 92, 37-49. [CrossRef]

183. Rodriguez-Saona, C.; Poland, T.M.; Miller, J.R.; Stelinski, L.L.; Grant, G.G.; de Groot, P.; Buchan, L.; MacDonald, L. Behavioral and electrophysiological responses of the emerald ash borer, Agrilus planipennis, to induced volatiles of Manchurian ash, Fraxinus mandshurica. Chemoecology 2006, 16, 75-86. [CrossRef] 
184. Ruehr, N.K.; Offermann, C.A.; Gessler, A.; Winkler, J.B.; Ferrio, J.P.; Buchmann, N.; Barnard, R.L. Drought effects on allocation of recent carbon: From beech leaves to soil $\mathrm{CO}_{2}$ efflux. New Phytol. 2009, 184, 950-961. [CrossRef]

185. Ruehr, N.K.; Law, B.E.; Quandt, D.; Williams, M. Effects of heat and drought on carbon and water dynamics in a regenerating semi-arid pine forest: A combined experimental and modeling approach. Biogeosciences 2014, 11, 4139-4156. [CrossRef]

186. Birami, B.; Gattmann, M.; Heyer, A.G.; Grote, R.; Arneth, A.; Ruehr, N.K. Heat waves alter carbon allocation and increase mortality of Aleppo pine under dry conditions. Front. For. Glob. Change 2018, 1, 8. [CrossRef]

187. Gattmann, M.; Birami, B.; Nadal Sala, D.; Ruehr, N.K. Dying by drying: Timing of physiological stress thresholds related to tree death is not significantly altered by highly elevated $\mathrm{CO}_{2}$. Plant Cell Environ. 2021, 44, 356-370. [CrossRef]

188. Hartmann, H.; Moura, C.F.; Anderegg, W.R.L.; Ruehr, N.K.; Salmon, Y.; Allen, C.D.; Arndt, S.K.; Breshears, D.D.; Davi, H.; Galbraith, D.; et al. Research frontiers for improving our understanding of drought-induced tree and forest mortality. New Phytol. 2018, 218, 15-28. [CrossRef] [PubMed]

189. Ruehr, N.K.; Grote, R.; Mayr, S.; Arneth, A. Beyond the extreme: Recovery of carbon and water relations in woody plants following heat and drought stress. Tree Physiol. 2019, 39, 1285-1299. [CrossRef] [PubMed]

190. Jacobs, S.R.; Breuer, L.; Butterbach-Bahl, K.; Pelster, D.E.; Rufino, M.C. Land use affects total dissolved nitrogen and nitrate concentrations in tropical montane streams in Kenya. Sci. Total Environ. 2017, 603-604, 519-532. [CrossRef] [PubMed]

191. Jacobs, S.; Weeser, B.; Guzha, A.; Rufino, M.; Butterbach-Bahl, K.; Windhorst, D.; Breuer, L. Using High-Resolution Data to Assess Land Use Impact on Nitrate Dynamics in East African Tropical Montane Catchments. Water Resour. Res. 2018, 54, 812-1830. [CrossRef]

192. Brandt, P.; Hamunyela, E.; Herold, M.; de Bruin, S.; Verbesselt, J.; Rufino, M.C. Sustainable intensification of dairy production can reduce forest disturbance in Kenyan montane forests. Agric. Ecosyst. Environ. 2018, 265, 307-319. [CrossRef]

193. Arias-Navarro, C.; Díaz-Pinés, E.; Zuazo, P.; Rufino, M.C.; Verchot, L.V.; Butterbach-Bahl, K. Quantifying the contribution of land use to $\mathrm{N}_{2} \mathrm{O}, \mathrm{NO}$ and $\mathrm{CO}_{2}$ fluxes in a montane forest ecosystem of Kenya. Biogeochemistry 2017, 134, 95-114. [CrossRef]

194. Wanyama, I.; Pelster, D.E.; Butterbach-Bahl, K.; Verchot, L.V.; Martius, C.; Rufino, M.C. Soil carbon dioxide and methane fluxes from forests and other land use types in an African tropical montane region. Biogeochemistry 2019, 143, 171-190. [CrossRef]

195. Woittiez, L.; Rufino, M.; Giller, K.; Mapfumo, P. The Use of Woodland Products to Cope with Climate Variability in Communal Areas in Zimbabwe. Ecol. Soc. 2013, 18, 24. [CrossRef]

196. Njue, N.; Stenfert Kroese, J.; Gräf, J.; Jacobs, S.R.; Weeser, B.; Breuer, L.; Rufino, M.C. Citizen science in hydrological monitoring and ecosystem services management: State of the art and future prospects. Sci. Total Environ. 2019, 693, 133531. [CrossRef] [PubMed]

197. Weeser, B.; Stenfert Kroese, J.; Jacobs, S.R.; Njue, N.; Kemboi, Z.; Ran, A.; Rufino, M.C.; Breuer, L. Citizen science pioneers in Kenya-A crowdsourced approach for hydrological monitoring. Sci. Total Environ. 2018, 631, 1590-1599. [CrossRef] [PubMed]

198. Sankey, T.; Belmonte, A.; Massey, R.; Leonard, J. Regional-scale forest restoration effects on ecosystem resiliency to drought: A synthesis of vegetation and moisture trends on Google Earth Engine. Remote Sens. Ecol. Conserv. 2020, 7, 259-274. [CrossRef]

199. Sankey, T. Regional assessment of aspen change and spatial variability on decadal time scales. Remote Sens. 2009, 1, 896-914. [CrossRef]

200. Sankey, T.; Donald, J.; McVay, J.; Ashley, M.; Masek Lopez, S.; O’Donnell, F.; Springer, A. Multi-scale analysis of snow dynamics at the southern margin of the North American continental snow distribution. Remote Sens. Environ. 2015, 169, 307-319. [CrossRef]

201. Sankey, T.; Donager, J.; McVay, J.; Sankey, J. UAV lidar and hyperspectral fusion for forest monitoring in the southwestern USA. Remote Sens. Environ. 2017, 195, 30-43. [CrossRef]

202. Shin, P.; Sankey, T.; Moore, M.; Thode, A. Evaluating unmanned aerial vehicle images for estimating forest canopy fuels in a ponderosa pine stand. Remote Sens. 2018, 10, 1266. [CrossRef]

203. Belmonte, A.; Sankey, T.; Biederman, J.; Bradford, J.; Goetz, S.; Kolb, T. UAV-based Estimate of Snow Cover Dynamics: Optimizing Semi-Arid Forest Structure for Snow Persistence. Remote Sens. 2021, 13, 1036. [CrossRef]

204. Sankey, T.; Hultine, K.; Blasini, D.; Koepke, D.; Bransky, N.; Grady, K.; Cooper, H.; Gehring, C.; Allan, G. UAV thermal image detects genetic trait differences among populations and genotypes of Fremont cottonwood (Populus fremontii, Salicaceae). Remote Sens. Ecol. Conserv. 2021, 7, 245-258. [CrossRef]

205. Satake, A.; Iwasa, Y. Pollen coupling of forest trees: Forming synchronized and periodic reproduction out of chaos. J. Theor. Biol. 2000, 203, 63-84. [CrossRef]

206. Satake, A.; Kawagoe, T.; Saburi, Y.; Chiba, Y.; Sakurai, G.; Kudoh, H. Forecasting flowering phenology under climate warming by modelling the regulatory dynamics of flowering-time genes. Nat. Commun. 2013, 4, 2303. [CrossRef] [PubMed]

207. Yeoh, S.H.; Satake, A.; Numata, S.; Ichie, T.; Lee, S.L.; Basherudin, N.; Muhammad, N.; Kondo, T.; Otani, T.; Hashim, M.; et al. Unravelling proximate cues of mass flowering in the tropical forests of South-East Asia from gene expression analyses. Mol. Ecol. 2017, 26, 5074-5085. [CrossRef] [PubMed]

208. Satake, A.; Kawatsu, K.; Teshima, K.; Kabeya, D.; Han, Q. Field transcriptome revealed a novel relationship between nitrate transport and flowering in Japanese beech. Sci. Rep. 2019, 9, 4325. [CrossRef]

209. Schulz, A.N.; Mech, A.M.; Cram, M.M.; Asaro, C.; Coyle, D.R.; Lucardi, R.D.; Lucas, S.; Gandhi, K.J.K. Association of Caliciopsis pinea Peck and Matsucoccus macrocicatrices Richards with eastern white pine (Pinus strobus L.) seedling dieback. For. Ecol. Manag. 2018, 423, 70-83. [CrossRef] 
210. Schulz, A.N.; Lucardi, R.D.; Marsico, T.D. Successful invasions and failed biocontrol: The role of antagonistic species interactions. BioScience 2019, 69, 711-724. [CrossRef]

211. Schulz, A.N.; Lucardi, R.D.; Marsico, T.D. Strengthening the ties that bind: An evaluation of cross-disciplinary communication between invasion ecologists and biological control researchers in entomology. Ann. Entomol. Soc. Am. 2021, 114, saaa052. [CrossRef]

212. Mech, A.M.; Thomas, K.A.; Marsico, T.D.; Herms, D.A.; Allen, C.R.; Ayres, M.P.; Gandhi, K.J.K.; Gurevitch, J.; Havill, N.P.; Hufbauer, R.A.; et al. Evolutionary history predicts high-impact invasions by herbivorous insects. Ecol. Evol. 2019, 9, 12216-12230. [CrossRef]

213. Sherriff, R.L.; Veblen, T.T. A spatially-explicit reconstruction of fire regime types in ponderosa pine forests of the Colorado Front Range. Ecosystems 2007, 10, 311-323. [CrossRef]

214. Sherriff, R.L.; Platt, R.V.; Veblen, T.T.; Schoennagel, T.L.; Gartner, M.H. Historical, observed, and modeled wildfire severity in montane forests of the Colorado Front Range. PLoS ONE 2014, 9, e106971.

215. Sherriff, R.L.; Berg, E.E.; Miller, A.E. Effects of interannual and multidecadal climate variability on spruce beetle (Dendroctonus rufipennis) activity in south-central and southwest Alaska. Ecology 2011, 92, 1459-1470. [CrossRef]

216. Sherriff, R.L.; Miller, A.E.; Muth, K.; Schriver, M.; Batzel, R. Recent tree-growth responses to warming vary by geographic region and ecosystem type within the boreal forest-tundra transition zone in Alaska. J. Biogeogr. 2017, 44, 1457-1468. [CrossRef]

217. Cocking, M.I.; Varner, J.M.; Sherriff, R.L. California black oak responses to fire severity and native conifer encroachment in the Klamath Mountains. For. Ecol. Manag. 2012, 270, 25-34. [CrossRef]

218. Vernon, M.; Sherriff, R.L.; van Mantgem, P.; Kane, J. Do fuel treatments promote resistance to multi-year drought in a mixed-conifer forest of northern California? For. Ecol. Manag. 2018, 422, 190-198. [CrossRef]

219. Snook, L.K. Catastrophic disturbance, logging and the ecology of mahogany (Swietenia macrophylla King): Grounds for listing a major tropical timber species in CITES. Bot. J. Linn. Soc. 2008, 122, 35-46. [CrossRef]

220. Snook, L. Regeneration, Growth, and Sustainability of Mahogany in México's Yucatán Forests; Springer: Berlin, Germany, 2003; pp. 169-192.

221. Boscolo, M.; Snook, L.; Quevedo, L. Adoption of Sustainable Forest Management Practices in Bolivian Timber Concessions: A Quantitative Assessment. Int. For. Rev. 2010, 11, 514-523. [CrossRef]

222. Snook, L.; Cámara-Cabrales, L.; Kelty, M. Six years of fruit production by mahogany trees (Swietenia macrophylla King): Patterns of variation and implications for sustainability. For. Ecol. Manag. 2005, 206, 221-235. [CrossRef]

223. Shono, K.; Snook, L. Growth of big-leaf mahogany (Swietenia macrophylla) in natural forests in Belize. J. Trop. For. Sci. 2006, $18,61-73$.

224. Snook, L.; Santos Jimenez, V.A.; Carreón Mundo, M.; Chan Rivas, C.; May Ek, F.J.; Mas Kantún, P.; Hernandez, C.; Nolasco Morales, A.; Escobar Ruíz, C. Managing natural forests for sustainable harvests of mahogany (Swietenia macrophylla): Experiences in Mexico's community forests. Unasylva 2003, 54, 68-73.

225. Velarde, S.; Sharma-Wallace, L.; Warmenhoven, T.; Pohatu, P.; Edwards, P.; Barnard, T. Policy design lessons from the Erosion Control Funding Programme-afforestation through an adaptive governance lens. N. Z. J. For. 2019, 64, 11-16.

226. Sharma-Wallace, L.; Velarde, S.; Edwards, P.; Warmenhoven, T.; Pohatu, P. Exploring Adaptive Governance for Indigenous Peoples: Lessons from Aotearoa New Zealand's Erosion Control Funding Programme. Soc. Nat. Resour. 2019, 33, 1-24. [CrossRef]

227. Sharma-Wallace, L.; Velarde, S.J.; Wreford, A. Adaptive governance good practice: Show me the evidence! J. Environ. Manag. 2018, 222, 174-184. [CrossRef]

228. Velarde, S.J. Adaptive Governance-A Toolkit for Action-Beta Version. 2018. Available online: https:/ /www.scionresearch.com/ science/sustainable-forest-and-land-management/adaptive-governance-a-toolkit-for-action (accessed on 23 December 2021).

229. Evans, K.; Velarde, S.; Rao, S.; Prieto, R.; Sertzen, S.; Davila, K.; de Jong, W.; Cronkleton, P. Field Guide to the Future: Four Ways for Communities to Think Ahead; CIFOR: Nairobi, Kenya, 2006; ISBN 978-979-24-4654-8.

230. Cambi, M.; Hoshika, Y.; Mariotti, B.; Paoletti, E.; Picchio, R.; Venanzi, R.; Marchi, E. Compaction by a forest machine affects soil quality and Quercus robur L. seedling performance in an experimental field. For. Ecol. Manag. 2017, 384, 406-414. [CrossRef]

231. Picchio, R.; Mercurio, R.; Venanzi, R.; Gratani, L.; Giallonardo, T.; Lo Monaco, A.; Frattaroli, A.R. Strip clear-cutting application and logging typologies for renaturalization of pine afforestation-A case study. Forests 2018, 9, 366. [CrossRef]

232. Sohrabi, H.; Jourgholami, M.; Jafari, M.; Shabanian, N.; Venanzi, R.; Tavankar, F.; Picchio, R. Soil recovery assessment after timber harvesting based on the sustainable forest operation (SFO) perspective in iranian temperate forests. Sustainability 2020, $12,2874$. [CrossRef]

233. Venanzi, R.; Picchio, R.; Spinelli, R.; Grigolato, S. Soil Disturbance and Recovery after Coppicing a Mediterranean Oak Stand: The Effects of Silviculture and Technology. Sustainability 2020, 12, 4074. [CrossRef]

234. Venanzi, R.; Picchio, R.; Grigolato, S.; Spinelli, R. Soil disturbance induced by silvicultural treatment in chestnut (Castanea sativa mill.) coppice and post-disturbance recovery. Forests 2020, 11, 1053. [CrossRef]

235. White, J.; Coops, N.; Wulder, M.; Vastaranta, M.; Hilker, T.; Tompalski, P. Remote Sensing Technologies for Enhancing Forest Inventories: A Review. Can. J. Remote Sens. 2016, 42, 619-641. [CrossRef]

236. White, J.; Wulder, M.; Vastaranta, M.; Coops, N.; Pitt, D.; Woods, M. The Utility of Image-Based Point Clouds for Forest Inventory: A Comparison with Airborne Laser Scanning. Forests 2013, 4, 518-536. [CrossRef] 
237. White, J.; Stepper, C.; Tompalski, P.; Coops, N.; Wulder, M. Comparing ALS and Image-Based Point Cloud Metrics and Modelled Forest Inventory Attributes in a Complex Coastal Forest Environment. Forests 2015, 4, 518-536. [CrossRef]

238. White, J.C.; Tompalski, P.; Coops, N.C.; Wulder, M.A. Comparison of airborne laser scanning and digital stereo imagery for characterizing forest canopy gaps in coastal temperate rainforests. Remote Sens. Environ. 2018, 208, 1-14. [CrossRef]

239. White, J.; Wulder, M.; Varhola, A.; Vastaranta, M.; Coops, N.; D Cook, B.; Pitt, D.; Woods, M. A best practices guide for generating forest inventory attributes from airborne laser scanning data using an area-based approach. For. Chron 2013, 86, 722-733. [CrossRef]

240. White, J.C.; Wulder, M.A.; Hermosilla, T.; Coops, N.C. Satellite time series can guide forest restoration. Nature 2019, 569, 630. [CrossRef]

241. White, J.C.; Wulder, M.A.; Hobart, G.W.; Luther, J.E.; Hermosilla, T.; Griffiths, P.; Coops, N.C.; Hall, R.J.; Hostert, P.; Dyk, A.; et al. Pixel-Based Image Compositing for Large-Area Dense Time Series Applications and Science. Can. J. Remote Sens. 2014, 40, 192-212. [CrossRef]

242. Zhao, X.; Zhao, P.; Zhang, Z.; Zhu, L.; Niu, J.; Ni, G.; Hu, Y.; Ouyang, L. Sap flow-based transpiration in Phyllostachys pubescens: Applicability of the TDP methodology, age effect and rhizome role. Trees 2017, 31, 765-779.

243. Zhao, X.; Zhao, P.; Zhang, Z.; Zhu, L.; Hu, Y.; Ouyang, L.; Ni, G.; Ye, Q. Culm Age and Rhizome Affects Night-Time Water Recharge in the Bamboo Phyllostachys pubescens. Front. Plant Sci. 2017, 8, 1928. [CrossRef] [PubMed]

244. Zhao, X.; Zhao, P.; Zhu, L.; Wang, Q.; Hu, Y.; Cranston, B.M.; Kaplick, J.; Lei, O.; Chen, X.; Ni, G.; et al. Exploring the Influence of Biological Traits and Environmental Drivers on Water Use Variations across Contrasting Forests. Forests 2021, 12, 161. [CrossRef]

245. Hu, Y.; Zhao, P.; Zhu, L.; Zhao, X.; Ni, G.; Ouyang, L.; Schäfer, K.V.R.; Shen, W. Responses of sap flux and intrinsic water use efficiency to canopy and understory nitrogen addition in a temperate broadleaved deciduous forest. Sci. Total Environ. 2019, 648, 325-336. [CrossRef]

246. Zhu, L.W.; Zhao, P.; Cai, X.A.; Zeng, X.P.; Ni, G.Y.; Zhang, J.Y.; Zou, L.L.; Mei, T.T.; Yu, M.H. Effects of sap velocity on the daytime increase of stem $\mathrm{CO}_{2}$ efflux from stems of Schima superba trees. Trees 2012, 26, 535-542. [CrossRef]

247. Zhu, L.; Zhao, P.; Ni, G.; Cao, Q.; Zhou, C.; Zeng, X. Individual- and stand-level stem $\mathrm{CO}_{2}$ efflux in a subtropical Schima superba plantation. Biogeosciences 2012, 9, 3729-3737. [CrossRef]

248. Zhu, L.W.; Zhao, P.; Wang, Q.; Ni, G.Y.; Niu, J.F.; Zhao, X.H.; Zhang, Z.Z.; Zhao, P.Q.; Gao, J.G.; Huang, Y.Q.; et al. Stomatal and hydraulic conductance and water use in a eucalypt plantation in Guangxi, southern China. Agric. For. Meteorol. 2015, 202, 61-68. [CrossRef]

249. Zhu, L.; Hu, Y.; Zhao, X.; Zeng, X.; Zhao, P.; Zhang, Z.; Ju, Y. The impact of drought on sap flow of cooccurring Liquidambar formosana Hance and Quercus variabilis Blume in a temperate forest, Central China. Ecohydrology 2017, 10, e1828. [CrossRef]

250. Nocco, M.A.; McGill, B.M.; MacKenzie, C.M.; Tonietto, R.K.; Dudney, J.; Bletz, M.C.; Young, T.; Kuebbing, S.E. Mentorship, equity, and research productivity: Lessons from a pandemic. Biol. Conserv. 2021, 255, 108966. [CrossRef]

251. Bernard, R.E.; Cooperdock, E.H. No progress on diversity in 40 years. Nat. Geosci. 2018, 11, 292-295. [CrossRef]

252. McIntosh, P. White Privilege and Male Privilege: A Personal Account of Coming to See Correspondences through Work in Women's Studies. 1988. Available online: https://www.collegeart.org/pdf/diversity/white-privilege-and-male-privilege.pdf (accessed on 23 December 2021). 